\title{
Nuevas reflexiones para la lectura iconográfica de la Portada del Perdón de San Isidoro de León: el impacto de la Reforma Gregoriana y el arte de la tardoantigüedad.
}

José Alberto Moráis Morán

Universidad de León

RESUMEN. La Puerta del Perdón, ubicada en el brazo sur del transepto de la iglesia de la Real Colegiata de San Isidoro de León, ha sido considerada por la historiografía tradicional como una obra fundamental del arte románico. Su escultura refleja las fuentes de las que se pudieron servir los artistas que llevaron a cabo tal obra. Entre ellas, se ha valorado el papel jugado por diversas producciones artísticas salidas de los talleres cristiano-primitivos de la tardía Antigüedad, así como el impacto ideológico de la Reforma Gregoriana. Todo ello, permite además indagar en las conexiones iconográficas existentes entre la portada y algunos centros hispanos del momento como la catedral de Santiago de Compostela o la iglesia de Santo Domingo de Silos, así como otros del ámbito europeo tales como la basílica de Saint Sernin de Toulouse o la abadía borgoñona de Cluny.

Palabras clave: Portada del Perdón, San Isidoro de León, Reforma Gregoriana, Antigüedad tardía, iconografía, escultura.

ABSTRACT. The Puerta del Perdón, located in the south transept arm of the royal monastery church of San Isidoro in León, has been considered by traditional historiography like a fundamental work of the Romanesque art. Its sculpture reflects the sources that could have been utilized by the artists who made that work. For example, it has been valued the role played by some artistic productions originated in early christian workshops of the Late Antiquity, and the ideological impact of the Gregorian Reform. All these things allow the investigation of the iconographic connections between the portal and some hispanic centres of that time like the Cathedral of Santiago de Compostela or the church of Santo Domingo de Silos, and like other european examples like the basilica of Saint Sernin de Toulouse or the burgundian abbey of Cluny.

Key words: Puerta del Perdón, San Isidoro de León, Gregorian Reform, Late Antiquity, iconography, sculpture.

La puerta del Perdón, ubicada en el hastial sur del transepto de la basílica de San Isidoro de León (fig. 1), ha sido considerada tradicionalmente por la historiografía, como una de las grandes obras del arte románico ${ }^{1}$. De ella se

-

${ }^{1}$ No existen estudios monográficos que aborden el análisis de la portada de manera exclusiva, ya que la mayoría de las referencias existentes a ella están incluidas en investigaciones generales del edificio o de la escultura de la Real Colegiata.

Recogemos aquí los trabajos que de una manera más profunda han incidido en diversos aspectos de dicha portada, evitando incluir las referencias o menciones, de carácter superficial, que de ella se han hecho: G. GAILLARD, Les débuts de la sculpture romane espagnole. León-JacaCompostelle, Paris, 1938, especialmente pp. 79-83; A. KINGSLEY POTER, Spanish romanesque sculpture, II vols., New York, 1969, vol. I, p. 62 y vol. III, p. 12, donde hace breves referencias sobre el estilo de su escultura.

\section{-}

Son de destacar también los estudios de: M. Durliat, La sculpture romane de la Route de Saint- Jacques. De Conques à Compostelle, Mont-de-Marsan, 1990, en concreto pp. 385-389; J. W. WiLliams, "León and the beginnings of the spanish romanesque", The art of Medieval Spain $a . d$. 500-1200, New York, 1993, pp. 167-173, en especial p. 170; I. BANGO TORVISO, "Arquitectura y escultura", Historia del Arte en Castilla y León. Arte Románico, t. II, Valladolid, 1994, pp. 9-212, especialmente p. 68; A. ViÑAYO GONZÁLEZ, "Real Colegiata de San Isidoro", Enciclopedia del románico en Castilla y León. León, Fundación Santa María la Real. Centro de Estudios Medievales del románico, Aguilar de Campoo, 2002, centrándose en el análisis de la fachada en las pp. 562-564 y M. POZA YAGÜE, "Entre la tradición y la reforma. A vueltas de nuevo con las portadas de San Isidoro de León", Anuario del Departamento de Historia y Teoría del Arte, XV, 2003, pp. 9-28. De manera más reciente, M. A. CASTIÑEIRAS GONZÁLEZ, "Topographie sacrée, liturgie pascale et reliques dans les centres de pèlegrinage: Saint-Jacques-de-Compostelle, Saint-Isidore-deLeón et Saint-Étienne-de-Ribas-de-Sil", Les Cahiers de 
ha destacado, no sólo su alta calidad escultórica, sino también su facilidad en el uso del lenguaje narrativo a través de la plástica y la destreza que el artista tuvo a la hora de sintetizar de manera clara y directa el programa iconográfico relativo a la crucifixión, entierro y ascensión de Cristo.

La portada de acceso presenta un abocinamiento realizado a través de una arquivolta doble que descansa en dos pares de columnas elevadas sobre basamento y basa ática. Sobre la puerta se esculpió un tímpano formado por tres placas independientes, pero totalmente relacionadas en cuanto a su iconografía. El tímpano se eleva a su vez sobre dos ménsulas en forma de prótomo cefálico animal. Flanqueando la puerta se colocaron sendas esculturas con la representación de San Pedro y San Pablo, enmarcados así mismo por una moldura en forma de arco decorado con el típico ajedrezado.

La separación de la parte inferior y superior de la fachada se llevó a cabo a través de una cornisa de una vertiente, decorada con canecillos figurados y taqueado, elementos éstos muy habituales dentro del léxico románico.

La parte superior se articula con una triple arquería enmarcada por ajedrezado que se sustenta en columnas con capitel corintio. Sólo el espacio central, de los tres existentes, presenta vano abierto ${ }^{2}$. El conjunto se cierra con un remate en forma de piñón. A su vez, toda la fachada, fue enmarcada por dos grandes contrafuertes de grosor decreciente y escalonado. En la parte alta de estos contrafuertes fueron colocadas las esculturas exentas de unos animales de difícil identificación.

La facilidad que dicho conjunto presenta a la hora de llevar a cabo una aproximación en

Saint-Michel de Cuxa, 34, 2003, pp. 27-49, especialmente en pp. 41-44, realiza una serie de observaciones en torno a algunos aspectos de la fachada, relacionándolos con la liturgia pascual y la penitencia.

${ }_{2}^{2}$ Parece ser que ésta fue la concepción original de la composición de los tres vanos, ya que las fuentes más antiguas que describen la fachada ya mencionan el hecho de que los dos vanos laterales sean ciegos, mientras que el central se describe abierto. A este respecto, Quadrado nos dice: "En los arcos semicirculares y decrecientes de su cegada puerta (refiriéndose a la Puerta del Perdón que por estos momentos debía estar completamente tabicada), y en los de las tres ventanas que a modo de galería corren en el segundo cuerpo sobre la ajedrezada cornisa, cerradas también a escepción de la del centro (...)": J. M $\mathrm{M}^{\mathrm{a}}$. QUADRADO, Recuerdos y bellezas de España. Asturias y León, 1855, (facsímil, Gijón, 1977), p. 339. su lectura iconográfica, contrasta con la complejidad de la problemática en lo que se refiere a su filiación y cronología; auténticos temas de debate dentro de los estudios en los que se ha tratado dicha portada. Actualmente se viene apuntando la posibilidad de que la Portada del Perdón fuese erigida entre los años 1112-1120, durante el reinado de Urraca, la hija de Fernando I y Sancha ${ }^{3}$.

\section{EL TRANSEPTO DE SAN ISIDORO DE LEÓN.}

Sin duda, uno de los grandes logros y originalidades, dentro de la arquitectura religiosa cristiana, es el desarrollo de la estructura arquitectónica del transepto ${ }^{4}$. Dicho elemento dio, desde los primeros tiempos del cristianismo, solución a la problemática espacial dentro del templo, además de convertirse en un espacio

${ }^{3}$ La complejidad para datar el conjunto artístico isidoriano es sobradamente conocida. Baste señalar los numerosos estudios y referencias que en torno a la cuestión cronológica existen; no sólo para el transepto de la iglesia de San Isidoro, sino también para la otra fachada conservada, la del Cordero y de manera más compleja si cabe para el propio Panteón Real, considerado por algunos autores como obra de Fernado I, de su esposa Sancha, o incluso de la hija de ambos, la reina Urraca. Recientemente T. MARTIN, "The art of a Reigning Queen as Dynastic propaganda in Twelfth Century Spain", Speculum, 80, 2005, pp. 1134-1171, especialmente pp. 1144 y 1156-1158, defiende el papel jugado por Urraca para la construcción del transepto isidoriano y por consiguiente de su fachada. Por el contrario, para M. Poza YaGüE, Op. cit. p. 20, la Puerta del Perdón habría sido realizada en torno a los últimos años de la primera década del siglo XII. La autora da por válida la fecha de 1112 para esta portada, es decir, supuestamente anterior a la fecha tradicionalmente aceptada para la portada Miègeville de Saint Sernin de Toulouse, con la que tantas veces se ha relacionado el conjunto escultórico de la portada leonesa. Sin embargo, M. A. CASTIÑEIRAS GonZÁLEZ, "Topographie...", p. 42, data el conjunto escultórico del hastial sur en torno al año 1120 .

${ }^{4}$ Recogemos aquí la definición dada por J. A. IÑIGUEZ, Síntesis de Arqueología cristiana, Ávila, 1977, p. 132, donde afirma que transepto es: "el espacio transversal entre la cabecera y las naves (...) la razón de porqué surge este elemento en la planta de la basílica no ha podido esclarecerse totalmente, pero el tenerla San Pedro del Vaticano y San Pablo Extramuros, (...) parece seguro su destino de culto martirial, quedando las naves para el sacrificial". Señala también el autor la caída en desuso de dicha estructura en el siglo VI con el desarrollo de la cripta, volviendo a recuperarse después en los templos de uso monástico como se ve en el caso de Quintanilla de las Viñas o San Pedro de la Nave.

Sobre la introducción del transepto en la iglesia monástica hispana, vid. I. G. BANGO TORVISO, "La iglesia monástica en la España medieval 500-1200", Monasterios románicos y producción artística, Aguilar de Campoo, 2003, pp. 215-229, particularmente pp. 215-219. 
fundamental para el desarrollo de la liturgia ceremonial, así como elemento jerarquizador del espacio sagrado. A través de él se accede al ábside central y laterales, puntos focales del culto cristiano, es el lugar donde a veces se colocó la schola cantorum, desde donde los fieles siguen la ceremonia y donde se llevan a cabo ritos procesionales.

Desde antiguo la edilicia paleocristiana utilizó el transepto dentro las más grandes basílicas, llevando a cabo una reutilización y reinterpretación de un espacio sobradamente conocido dentro de los grandes templos y espacios públicos de la arquitectura romana ${ }^{5}$. El caso más conocido dentro de la tardoantigüedad fue el de la basílica romana de San Pedro del Vaticano, auténtico modelo a seguir e imitado en toda la cristiandad $^{6}$. No en vano, cuando en plenos siglos XI y XII, se levantaron sobre las basílicas

${ }^{5}$ Sobre la evolución de la basílica romano-pagana hasta el modelo arquitectónico reinterpretado en la basílica cristiana, vid.: F. CABROL Y H. LECLERQC, voz "Basilique", Dictionnaire d'Archélogie Chrétienne et de liturgie, vol. II, B, Paris, 1914, cols. 525-602

${ }^{6}$ Sobre el transepto vaticano y sus repercusiones en la Roma paleocristiana y medieval ver F. GALTIER MARTí, $L a$ iconografía cristiana en el arte cristiano del primer milenio. Perspectiva y convención; sueño y realidad, Huesca, 2001. El modelo creado en San Pedro del Vaticano pasará de manera íntegra a construcciones de la envergadura de Santa Práxedes, San Crisógono o San Clemente, todas ellas en la ciudad de Roma. Para el caso concreto de Santa Práxedes, que sigue con total fidelidad el modelo de la basílica constantiniana, pero de menor tamaño, véase, Ibidem, p. 314. Nos interesa señalar, no obstante, la adscripción del edificio que hace Galtier Martí al fenómeno de renovatio e imitación de obras tardoantiguas, que acaeció en la ciudad de Roma en torno al mandato de Pascual I y que tuvo como insignia base la asimilación, imitación y copia de los modelos del primer arte cristiano, embebidos aún en la más pura tradición clásica.

Sabemos que la primera basílica dedicada al apóstol en Roma, la constantiniana, poseía un gran transepto continuo que sería imitado ya en el santuario de San Pablo de Roma del año 385. De nuevo serán los carolingios los que, tomando como modelo una estructura tardoantigua de raigambre clásica, creen un prototipo constructivo de uso habitual en el ámbito europeo altomedieval: R. KRAUTHEIMER, Arquitectura paleocristiana y bizantina, Madrid, 1984, especialmente p. 66 y nota 41 de pp. 533-534.

En la misma línea, W. WeISBACH, Reforma religiosa y arte medieval. La influencia de Cluny en el románico occidental, Madrid, 1949, p. 20, considera que el resurgir del modelo basilical paleocristiano en ámbito alto medieval, debe atribuirse al imperio carolingio, que de manera consciente va a recuperar este modelo constructivo romano. Tal afirmación, es perfectamente visible en la iglesia abacial de Fulda donde el modelo de San Pedro del Vaticano está presente, en un síntoma más de la renovatio que vivía la ciudad de Roma en torno a los mandatos de los papas Leon III (795-816) y Pascual I (817-824). paleocristianas las nuevas construcciones, ahora en lenguaje románico, la estructura planimétrica de los edificios de la tardía Antigüedad sobrevivió de manera mimética, justificando de esta manera su inclusión dentro de lo que se ha dado en llamar "renacimiento paleocristiano" 7. A pesar de que este nuevo interés por la recuperación de los lenguajes del arte paleocristiano es especialmente visible desde el punto de vista iconográfico, podemos aplicarlo también a las estructuras edilicias de la arquitectura religiosa; hecho visible en el recurrente uso de atrios, nartex y transeptos. Entendemos entonces, que tanto en el ambiente arquitectónico europeo, como en el hispano, la estructura del transepto de las basílicas paleocristianas, fue asumida y difundida de manera frecuente ${ }^{8}$.

${ }^{7}$ El término "renacimiento paleocristiano" debe ser utilizado con cautela. Según H. TOUBERT, "Le renouveau paléochrétien à Rome au début du XIIè siècle", Cahiers Archéologiques, XX, 1970, pp. 99- 154, es especialmente visible en la Roma de finales del siglo XI, donde observamos una recuperación consciente de modelos nacidos en el arte de las primeras comunidades cristianas. El fenómeno se deja entrever también en determinadas iconografías de tradición clásica y paleocristiana. Para el caso español son importantes los estudios de D. OCÓN ALONSO, "El sello de Dios sobre la iglesia: tímpanos con crismón en Navarra y Aragón”, El tímpano románico. Imágenes, estructuras y audiencias, Santiago de Compostela, 2003, pp. 75-101, sobre todo p. 93. También, M. A. CASTIÑEIRAS GONZÁLEZ, "La catedral románica: tipología arquitectónica y narración visual", Santiago, la Catedral y la memoria del arte, Santiago de Compostela, 2000, pp. 39-96, particularmente p. 65. Ambos autores usan el término "renacimiento paleocristiano" y analizan varios ejemplos para justificar su existencia dentro del arte románico peninsular.

${ }^{8}$ En la Península Ibérica encontramos transeptos fuertemente desarrollados en planta desde los inicios de la actividad constructiva de las primeras comunidades cristianas. Es el caso del gran transepto marcado en planta que muestra la basílica de Recópolis o Zorita de los Canes en Guadalajara, un ejemplo que justifica el gran desarrollo que dicho elemento va a tener en las construcciones visigodas. Aunque si bien esta estructura dista mucho del uso que en época plenomedieval se le va a dar al transepto, pues tal y como señala P. DE PALOL, Arqueología cristiana de la España romana. Siglos IV-VI, Madrid-Valladolid, 1967, pp. 90-93, se trata de "un templo de tres naves, con cámaras laterales en forma de transepto (...)". El autor considera también, que durante el siglo VI, en el que data el edificio, la frecuencia en el uso del transepto parece convertirse, junto con el uso de una sóla nave y un solo ábside, en características enteramente hispánicas.

Ejemplo de transepto desarrollado en planta lo ofrece la iglesia cacereña de Santa Lucia del Trampal, donde se marca no sólo en planta sino en alzado, a través de tres fuertes volúmenes exteriores a modo de cimborrios. La misma idea, aunque con menos recursos, aparece representada por el transepto de Santa María en Quintanilla de las Viñas, a pesar de que sólo podemos demostrar este dato a 
El último eslabón viene representado por la distribución planimétrica del espacio eclesial de Cluny, donde se tuvieron "en cuenta tendencias retrospectivas al adoptar como idea para su plano el de la basílica de San Pedro de Roma". Siguiendo esta línea, debemos centrarnos ahora en las experiencias que por estos momentos se estaban desarrollando en ámbito hispano.

Sabemos que en torno al año 1100 , se estaba levantando un transepto en la tercera reforma de la iglesia de Santo Domingo de Silos (fig. 2), convirtiéndose en una de las obras pioneras, en la Hispania de principios del siglo XII, en usar este elemento ${ }^{10}$.

partir de las excavaciones hechas en el perímetro de las partes de la iglesia derruida: I. G. BANGO TORVISO, Arte prerrománico hispano. El arte de la España cristiana de los siglos VI al IX, Madrid, 2001, pp. 108-113 y 96-101.

Dentro de los edificios asturianos, el caso más llamativo lo representa el transepto de San Julián de los Prados en Oviedo. Generalmente se ha venido considerando dicha estructura como heredera directa de los modelos paleocristianos y visigodos, en concreto el que supone Santa María de Quintanilla de las Viñas, tal y como apunta J. YARZA, Arte y Arquitectura en España 500-1250, Madrid, 1987, pp. 48-49. Esta misma teoría defiende G. GiOTTA, "La chiesa prerrománica asturiana di San Julián de los Prados a Oviedo. Iconografia, sistemi construttivi e partiti decorativi", Arte d'Occidente. Studi in onore di Angiola Maria Romanini. Temi e metodi, Roma, vol. I, 1999, pp. 49-59, particularmente p. 54, donde considera el transepto de Santullano como un trasunto del de Quintanilla de las Viñas, alejando el modelo astur de su posible origen carolingio, a favor de su carácter eminentemente hispano. También, A. ARBEITER, voz "Asturie", Enciclopedia dell'arte medievalle, II, Roma, 1991, pp. 672-681, en particular p. 677, considera que si bien el origen arquitectónico del edificio asturiano es diferente al que poseen el resto de las iglesias rurales de época visigoda, sin duda sus características tipológicas se encuentran todavía inmersas en la tradición de las grandes iglesias urbanas de época paleocristiana y visigoda. El caso del transepto de San Julián de los Prados señala el total conocimiento que de dicha estructura se tenía dentro de la edilicia de la más temprana arquitectura altomedieval peninsular hispana.

${ }^{9}$ Estas son las palabras utilizadas por W. WEISBACH, $O p$. cit., p. 50. Sobre el conjunto abacial de Cluny, sigue siendo fundamental la obra de J. K. CONANT, Cluny. Les églises et la maison du chef d'ordre, Mâcon, 1969.

${ }^{10}$ A este respecto I. G. BANGO TORVISO, "La antigua iglesia de Silos: del prerrománico al románico pleno", El románico en Silos. IX Centenario de la consagración de la iglesia y el claustro, Burgos, 1989, pp. 317- 376, especialmente p. 357, considera que la construcción del crucero silense fue en cierta medida una creación espontánea, provocada por una creciente necesidad de espacio, lo que les llevó a adoptar "una solución muy propia de la topografía templaria monástica a partir del crucero de la iglesia de Cluny". Estaríamos entonces ante uno de los primeros cruceros construidos en suelo hispano, de idéntica cronología incluso al levantado en Santiago de Compostela y que
Sin embargo, tal y como apunta I. Bango Torviso, el origen de tal estructura debemos buscarlo no en suelo hispano, sino foráneo. Así, todo parece apuntar que la causa que llevó a construir este elemento y darle la importancia que tomó dentro del cuerpo basilical de la iglesia levantada por el sucesor de Domingo Manso, el abad Fortunio, estaba en suelo francés y más concretamente en la Maior Ecclesia, es decir la abadía de Cluny ${ }^{11}$.

De nuevo un ejercicio de retrospectiva, nos ofrecerá la clave para comprender el origen último del transepto construido en la basílica de San Isidoro de León. En este sentido, debemos ser conscientes del proceso; ya que para que la edilicia altomedieval llegara a este grado de desarrollo en lo referente al transepto, tuvo que participar de la larga serie de experiencias artísticas que la arquitectura cristiana había llevado a cabo desde periodos tardo antiguos.

De ellas derivaron sin duda los grandes transeptos hispanos; tal y como demuestran los tempranos de San Miguel de Cuixá y Ripoll ${ }^{12}$, el citado de la tercera iglesia de Silos, el coetáneo

sin duda tendría repercusiones directas sobre el posterior de San Isidro de Dueñas, San Isidoro de León, San Benito de Sahagún o el de San Vicente de Ávila. Mayor complejidad presenta el transepto no marcado en planta de San Pedro de Arlanza, sobre esta cuestión véase, M. D. TEIJEIRA PABLos Y J. VALLEJo BozAL, "Fuentes para el estudio de la iglesia del monasterio de San Pedro de Arlanza en los inicios del románico pleno en España", Boletín de Museo Arqueológico Nacional, XIII, 1995, pp. 55-70, en especial p. 66. Sobre la cronología y fases de la iglesia de Santo Domingo de Silos, en concreto la datación del crucero en torno a la fecha de 1100 , véase también I. G. BANGO TORVISO, "La iglesia monástica...", en particular p. 219.

${ }^{11}$ El profesor Bango plantea la posibilidad de que la estructura del transepto llegara a los grandes monasterios castellanos a través de los contactos con las producciones artísticas catalanas, que a su vez se encontraban inmersas dentro de las experiencias artísticas que desde el ámbito borgoñón producía Cluny: "el transepto de Silos representa un hito intermedio entre los catalanes del primer románico y todos los hispanos del tardorrománico": I. G. BANGO TORVISO, "La antigua iglesia...," p. 357, nota 210.

${ }^{12}$ La iglesia de San Miguel de Cuixá, fue consagrada por el abad Guarinus el 28 de septiembre de 974, su cabecera de tipo "benedictino", estaba formada por cuatro ábsides semicirculares que flanqueaban un presbiterio de perímetro cuadrangular. Todos ellos abrían a un gran crucero, siguiendo el modelo borgoñón de Cluny II, tal y como apunta el profesor Bango: I. G. BANGO TORVISO, "La iglesia monástica...", p. 218.

En Santa María de Ripoll, consagrada el 1 de enero de 1032, se optó igualmente por un crucero con siete ábsides en batería, véase Ibidem, p. 218. 
espacio transversal de la basílica compostelana ${ }^{13}$ y los que poco tiempo después se levantarían en San Isidoro de León (fig. 3) y su homónimo de San Benito de Sahagún ${ }^{14}$ (fig. 4), entre otros.

Finalmente, y en lo referente al transepto de San Isidoro, sabemos, según se viene considerando tradicionalmente, que la planta de la basílica isidoriana, sufrió en un momento de su construcción, muy posiblemente en torno a los primeros años del siglo XII, una nueva reestructuración y reampliación que llevó a añadir a la estructura de las naves existentes, y de lenguaje plenamente románico, un cuerpo transversal a modo de transepto que provocó la reorganización de toda la zona de la cabecera y la consecuente descompensación de tamaño, espacialidad y concordancia entre las naves edificadas y el nuevo espacio construido ${ }^{15}$.

${ }^{13}$ Para la datación del transepto de la catedral de Santiago seguimos en todo momento la propuesta de S. MORALEJO, "La primitiva fachada norte de la Catedral de Santiago", Patrimonio artístico de Galicia y otros estudios, A. Franco Mata (ed.), Santiago de Compostela, 2004, vol. I, pp. 21-46, en especial pp. 43-46. El estudioso señala las fechas de 1100-1115 como factibles para la realización de la puerta del brazo norte del transepto compostelano. También ID. "Notas para una revisión de la obra de K. J. Conant", Patrimonio artístico..., vol. I, pp. 247-263, particularmente pp. 258-259. La cronología es ratificada por M. A. CASTIÑEIRAS GONZÁLEZ, "La catedral románica: tipología arquitectónica y narración visual", Santiago, la Catedral y la memoria del arte, Santiago de Compostela, 2000, pp. 39-96.

${ }^{14}$ El templo de San Benito de Sahagún presentaba a finales del siglo XI, una cabecera con tres ábsides antecedidos por un tramo recto no muy desarrollado, similares, según se ha dicho, a otros edificios del ámbito hispano coetáneos al edificio sahaguntino, tales como la catedral de Jaca, San Martín de Frómista, San Isidoro de Dueñas y, en última instancia, el primer San Isidoro de Léon. Véase sobre el tema, M. V. Herráez Ortega, C. Cosmen Alonso, E. FERNÁNDEZ GONZÁLEZ Y M. VALDÉS FERNÁNDEZ, "La renovación del monasterio en el reinado de Alfonso VI", Esplendor y decadencia de un monasterio medieval. El Patrimonio artístico de San Benito de Sahagún, (M. Victoria Herráez Ortega, coord.), León, 2002, pp. 51-77, en especial p. 67. Los autores datan la comentada estructura de San Benito de Sahagún en torno a la segunda mitad del siglo XII, por considerar que se trata de un léxico constructivo y decorativo de características muy avanzadas y evolucionadas.

15 Según T. MARTin, “The art...”, pp. 1142 y 1158, el crucero y las portadas estarían finalizados en torno al año 1124 , tal y como se nos dice en la consecratio del ábside norte. La autora considera el transepto isidoriano como un remedo del construido años antes en Santiago de Compostela y lo conecta con el existente en las grandes iglesias de peregrinación francesas, es decir con el existente en San Sernin de Toulouse, San Martín de Tours, San Martial de Limoges o Santa Fe de Conques. Sin embargo, a nuestro
Con todo ello, no parece arriesgado considerar, que de la misma manera que las grandes basílicas italianas altomedievales, como la de Santa Práxedes en Roma o la del monasterio de Montecassino, fueron pioneras en la construcción de un cuerpo transversal a modo de transepto, a imitatio del existente en la basílica constantiniana de San Pedro del Vaticano ${ }^{16}$; debemos entender que idéntico origen tiene el que varios siglos después se va a elevar en la propia iglesia de Cluny.

La estructura sería tomada por todas aquellas construcciones que durante este periodo se encontraban adscritas a la órbita de la abadía borgoñona, cabeza de serie del comentado prototipo basilical de transepto desarrollado en planta y alzado. San Isidoro de León, se encontraba sin duda en esa órbita desde el punto de vista político y artístico ${ }^{17}$.

modo de ver, el transepto leonés nada tiene que ver con aquellos, ni por tamaño ni por resolución arquitectónica.

${ }^{16}$ W. WeISBACH, Op. cit., pp. 67-69. Igualmente F. GANDOLFO, "La pintura romana tra XI e XII secolo e 1'Antico", Roma, centro ideale della cultura dell'Antico nei secoli XV e XVI. Da Martino V al Sacco di Roma 14171527, Milano, 1985, pp. 21-32, especialmente p. 26, considera que la decoración y arquitectura promovida por el abad Desiderio de Montecassino, tuvo muy en cuenta las experiencias artístiscas de las grandes basílicas paleocristianas romanas.

${ }^{17}$ La teoría expuesta hasta aquí es totalmente opuesta a la ofrecida por J. L. SENRA GABRIEL Y GALÁN, “Ángeles en Castilla: reflexiones en torno a renovación monástica $\mathrm{y}$ arquitectura en el siglo XI". Patrimonio artístico..., vol. III, pp. 261-274, particularmente pp. 270-274, en las que el autor rastrea el panorama arquitectónico hispano de finales del siglo XI buscando una posible influencia de la arquitectura borgoñona y en concreto la de Cluny. Concluye que nos encontramos ante una "nula expansión de este modelo de cabecera benedictina y, en general, en los limitados tamaños de los templos (...) tan sólo el excepcional caso de la catedral de Santiago de Compostela, activada por una masiva afluencia de peregrinos y una progresiva acumulación de reliquias, muestra la temprana adopción de tan ambicioso como inaugural proyecto arquitectónico cristalizado en una formidable catedral románica". Pone el caso del monasterio de San Benito de Sahagún y el de Silos como cabeceras de tipo benedictino, dejando claro que fueron construidas ya en la primera mitad del siglo XII. Para el caso que nos ocupa; considera que el transepto de San Isidoro de León fue levantado a lo largo del siglo XII en una readaptación de la planta de la iglesia, sin embargo afirma que tampoco en este caso la adopción de la cabecera benedictina parece clara, pues no se llevaron a cabo "altares monumentalizados por ábsides en cada uno de sus brazos", Ibidem, p. 274, nota 74 .

Por el contrario para T. MARTIN, “The art...”, p. 1158, las similitudes entre el transepto de Santiago de Compostela y el de San Isidoro de León son absolutamente evidentes, hasta el punto de considerar el buque transversal de la 


\section{LAS ARTES TARDOANTIGUAS CRISTIA- NAS Y SU RELACIÓN CON LA ESCULTU- RA MONUMENTAL ROMÁNICA.}

La llamada Puerta del Perdón, ha sido objeto de estudio en numerosas ocasiones, tal y como hemos señalado al principio de este trabajo. En su tímpano (fig. 5) se distribuyen escenas de la vida de Cristo: la crucifixión, que ocupa la parte central de la composición, flanqueada por las Marías ante el sepulcro vacío, ubicada a la derecha y la Ascensión, en el lado izquierdo ${ }^{18}$.

Para lo que concierne a nuestro trabajo, nos centraremos únicamente en el análisis de una serie de aspectos concretos y particulares de estas representaciones, dejando para el final una posible lectura global del conjunto.

basílica legionense como una evocación del compostelano. Opinión, que tal y como hemos señalado no compartimos.

Sobre la Reforma Gregoriana, su implantación en el ámbito hispano, así como su impacto sobre las artes, cf. W. WeISBACH, Op. cit. en concreto pp. 125-126, donde se centra en las repercusiones de este fenómeno sobre la escultura del Panteón de San Isidoro de León. Para el caso de San Isidoro de León y sus relaciones con la órbita cluniacense, cf. CH. BishKO, "Liturgical Intercesión at Cluny for the King-Emperors of León”, Studia Monastica, III, 1961, pp. 53- 76; ID. "The Liturgical context of Fernando I's last days according to the so-called Historia Silense", Miscelánea en Memoria de Don Mario Férotin (1914- 1964), Hispania Sacra, XVII- XVIII, 1964-1965, pp. 47-59.

${ }^{18}$ Nos encontramos ante un ciclo iconográfico que tiene sus raíces en las producciones artísticas del primer arte cristiano. A modo de comparación temática, proponemos las conocidas puertas lígneas de la basílica romana de Santa Sabina, donde de manera completa se ha representado el ciclo completo de la Pasión y la Resurrección, presentando además ciertas originalidades iconográficas precisamente en temas como la Crucifixión y la Ascensión a los cielos; véase S. TsuJI, "Les Portes de Sainte Sabine. Particularités de 1'Iconographie de 1'Ascension", Cahiers Archéologiques, XIII, 1962, pp. 13-28, particularmente p. 13. No en vano se considera que la crucifixión representada en estas puertas es la primera en su género dentro de la iconografía cristiana, donde aparecen los crucificados a modo de orantes, sin duda emulando la forma de la cruz: véase, R. MiLBURN, Early Christian art and architecture, Aldershot, 1988, pp. 108110. La reiteración temática del arte paleocristiano parece evidente dentro de la escultura de finales del siglo XI; "en todas las pinturas que cubren los muros y techos de las catacumbas aparecen constantemente la resurrección, la salvación y la vida después de la muerte", tal y como señala J. BECKWITH, Arte paleocristiano y bizantino, Madrid, 1997, p. 24. La misma idea expone A. GRABAR, Las vías de la creación iconográfica cristiana, Madrid, 1985, p. 129 y P. DE PALOL, Arte paleocristiano en España, Barcelona, 1968 , pp. 8-10, quién entiende como temas de origen paleocristiano, la redención, la salvación del alma humana y la ascensión.
Dentro del programa iconográfico de la Puerta del Perdón, advertimos desde un primer nivel de identificación temática, un marcado carácter escatológico y teofánico, sobradamente conocido en la iconografía románica ${ }^{19}$, pero cuyo origen y difusión, debemos atribuir al arte surgido en el seno de las primeras comunidades cristianas.

Como veremos, muchas de las portadas vinculadas al periodo reformador, entre las que se encuentra la del Perdón, presentarán de una manera u otra esta misma significación, buscando la exaltación de la figura de Cristo como Salvador y cumplidor de su promesa de redención $^{20}$. Si el trasfondo ideológico para este conjunto temático debe buscarse dentro de las ideas difundidas por la Reforma Gregoriana, son muchos los autores que no sólo han recurrido al pensamiento del periodo paleocristiano y tardoantiguo para buscar el origen de dichas representaciones, sino que han puesto sus miradas en las producciones artísticas ligadas a ese periodo en busca de posibles fuentes de inspiración.

Así, tal y como apuntó el profesor Serafín Moralejo, sería la iconografía tardoantigua romana la que presentaría el prototipo y modelo seguido para crear la escultura de la Puerta del Perdón de San Isidoro ${ }^{21}$. En concreto aludía al

\section{-}

${ }^{19}$ Sabemos que parte del programa iconográfico de la Maior Ecclesiae de Cluny estaba aparentemente concebido para exaltar la figura de Cristo a través de las visiones teofánicas; hecho factible a través de la representación de un Cristo en teofanía en la gran pintura mural del ábside, figurado como gran Pantócrator. Nuevamente un Cristo en teofanía volvería a ser representado en el gran acceso occidental del edificio, donde Cristo hierático en Majestad aparecía expresando uno de los valores más importantes dentro del ideario de la Reforma Gregoriana: Cristo Salvador como Rey del Cielo: W. WeISBACH, Op. cit., p. 141. El autor data esta fachada entre los años 1109-1115.

${ }^{20}$ Debido en parte a la gran disparidad de temas ligados a la exaltación de la figura de Cristo en teofanía, ya que como sabemos, el tema de la Ascensión de Cristo a los cielos, podría ser sustituido por otros afines, como la Ascensión de Helías, la Transfiguración, o diversas visiones escatológicas, que hacen que este tema iconográfico presente variantes de la más diversa índole, Ibidem, p. 25.

${ }^{21} \mathrm{~S}$. MORALEJO, "Modelo, copia y originalidad en el marco de las relaciones artísticas hispano-francesas (siglos XI- XIII)", Patrimonio artístico..., vol. I, pp. 75-96, particularmente pp. 98-100, donde el autor considera un díptico del siglo V, en el cual se representa la apotheosis de un emperador, como el modelo inspirador que siguieron los artífices románicos para crear la portada de Miègeville de Toulouse y por conguiente la Puerta del Perdón de San Isidoro de León, en la que se observa idéntico sistema compositivo para la escena de la Ascensión. Incluso afirma que la organización 
díptico de marfil llamado de $\mathrm{Symmachi}^{22}$ (fig. 6), donde en la parte izquierda del registro superior se representó la iconografía de la elevatio ad sidera mediante la cual el emperador pasaba a ser divinizado, es decir pasaba a convertirse en divus. Para ello la figura del soberano es ayudado por dos genios alados, posiblemente Aiones, que le impulsan en su tránsito al otro mundo ${ }^{23}$.

Las similitudes existentes entre la composición pagano-romana y la del tímpano leonés, no deben ser consideradas como un fenómeno aislado y extraordinario. Parece relativamente evidente que toda la imaginería imperial romana usada para narrar la ceremonia de apotheosis tuvo mucho que ver en la formación del tema iconográfico de la Ascensión a los cielos de Cristo $^{24}$. Al menos ello se deduce al observar algunos de los más conocidos ejemplos de elevatio ad sidera del mundo antiguo y primitivo cristianismo, donde la elevación al cielo por medio de seres o genios alados que llegan a tocar al emperador para

rigurosa tripartita que presenta la portada leonesa, sigue el sistema compositivo de los trípticos en marfil, hecho que nos vincula de nuevo a una tradición hispanolanguedociana.

22 Conservado en el British Museum de Londres.

${ }^{23}$ Esta es la interpretación que de la escena de apotheosis nos ofrece J. ARCE, Funus Imperatorum. Los funerales de los emperadores romanos, Madrid, 1988, p. 153. Interesante resulta la interpretación que hace del zodiaco superior, como elemento cosmológico que separa el mundo material y real, del superior y divino; allí donde le recibirán personajes como los siete sabios, Sócrates y seres mitológicos como las Musas.

${ }^{24}$ Para la escena de la apotheosis romana de los emperadores y las deudas que la iconografía cristiana de la Ascensión tiene con ella vid. A. GRABAR, Las vías de la creación iconográfica..., pp. 42-43 y 111. Además el autor considera como elemento fundamental para este determinado tipo de escena la aureola de luz, que envuelve al emperador en su tránsito. Este dato es importante, pues veremos como el simbolismo de la luz sería retomado en el mundo medieval de manera completa en lo relativo a la escena de la Ascensión. Esto explicaría algunas de las personificaciones que en ocasiones aparecen vinculadas a la Ascensión y Crucifixión de Cristo. De esta manera acompañando a la aureola de luz encontramos otra serie de fenómenos cosmológicos celestes, como las personificaciones de la luna, el sol y las estrellas, que remarcan el carácter de Dios como Rey de los Cielos. Sobre el tema vid. ID. "L'iconographie du Ciel dans 1'art Chrétien de 1'Antiquité et du Haut Moyen Âge", Cahiers Archeologiques, 30, Paris, 1982, especialmente p. 11. También S. TSUJI, Op. cit., p. 18, ve un origen pagano en la iconografía cristiana de la Ascensión. empujarlo literalmente hacia su nuevo destino, fue habitual ${ }^{25}$.

Siguiendo esa misma distinción, W. Weisbach utiliza idéntica terminología para describir el desarrollo iconográfico de otra de las grandes portadas adscritas al ambiente de la Reforma Gregoriana: la Puerta Miègeville de Saint-Sernin de Toulouse (fig. 7), donde de nuevo "el artista se ha ceñido a un modelo iconográfico extendido en el Occidente y que remonta a un prototipo paleocristiano helenístico,

-

${ }^{25}$ Este tipo de iconografía salvífica entronca dentro de las dos distinciones de elevación al cielo que tradicionalmente se han venido aceptando. Así, según S. TsuJI, $O p$. cit., p. 16, el tipo de iconografía representado en el díptico Symmachi, estaría dentro del tipo de la llamada latina, occidental o helenística, donde la elevación del emperador es llevada a cabo literalmente mediante el contacto físico con los genios que le ayudan en el tránsito; diferenciándose del otro tipo establecido, la oriental o siriopalestina donde el contacto con la figura divina es inexistente y donde la ascensión pierde visos de realidad para pasar a ser dotada de carácter sobrenatural.

En el ámbito hispano la iconografía de la ascensión a los cielos mediante el contacto físico entre la divinidad y el difunto, no fue en ningún caso desconocida. Así el llamado sarcófago de Santa Engracia de la catedral de Zaragoza, obra datada por P. Palol entre los años 340 y 350 , certifica el conocimiento en suelo hispano de este tipo de ascensión. El personaje en cuestión, Floria, identificado mediante epígra$\mathrm{fe}$, es literalmente empujado por la dextera domini a llevar a cabo la ascensión, o lo que es lo mismo, nos encontramos ante un caso de la conocida iconografía recepta ad Deum en la que la difunta recibe el milagro y la gracia divina ante dos testigos: PETRVUS y PAULVUS, apóstoles que desde las primeras manifestaciones artísticas paleocristianas se convertirán en testigos de excepción de los milagros y hechos llevados a cabo por la figura de Cristo. Tal y como veremos esta tradición figurativa tendrá una enorme difusión en las fachadas esculpidas de finales del siglo XI. Sobre el llamado sarcófago de la cripta de Santa Engracia, o también llamado de "La Ascensión", véase: P. DE PALOL, Arqueología cristiana..., pp. 302-303. También llama la atención sobre el sepulcro español, S. TsuJI, Op. cit., p. 19. Sin embargo esta peculiaridad iconográfica de tradición paleocristiana nunca se perdió del todo en el ámbito hispano, pues pocos siglos después encontramos idéntico tipo de elevatio en la representación iconográfica de Cristo y la Virgen, en formato capitel-imposta de la iglesia visigoda de Quintanilla de las Viñas. En este caso las figuras centrales aparecen flanqueadas por sus respectivas figuras angélicas que de manera directa tocan y entran en contacto físico con el cuerpo de Cristo y de la Virgen para ayudarles en la Ascensión. El sistema compositivo es del todo similar al utilizado para las imagines clipeatae de SOL y LVNA, de la misma iglesia y que también se han emparentado con las personificaciones romanas o cristianas seguidoras de una tradición atestiguada por ejemplo, en el sarcófago romano de San Pedro de Huesca: P. DE PAlOL y G. RiPOLl, Los godos en el Occidente Europeo. Ostrogodos y Visigodos en los siglos V-VIII, Madrid, 1988, p. 236. 
que hace ascender a Cristo en dirección oblicua hacia la derecha"26.

En Saint Sernin de Toulouse ${ }^{27}$ encontramos, si seguimos las teorías aceptadas tradicionalmente, el modelo iconográfico medieval, que no antiguo, para la representación leonesa. De esta manera aparece representada en la parte central del tímpano idéntica escena de elevación al cielo del tipo helenístico, donde el Señor asciende al cielo visto de perfil con los brazos levantados y el libro de la doctrina en su mano. También de nuevo aquí encontramos la reinterpretatio christiana de los genios alados en forma ahora de ángeles que le ayudan en su impulso ascensional ${ }^{28}$.

Llegados a este punto debemos preguntarnos por el origen común de estas dos portadas y sobre todo por el ámbito artístico en el que los iconógrafos, pensadores y artistas del movimiento reformador se estaban moviendo. Parece claro que las fuentes tardoantiguas y paleocristianas estaban perfectamente asimiladas en el Cluny de los siglos XI y XII, habida cuenta del profundo conocimiento que de las producciones artísticas antiquizantes parecen mostrar las artes que bajo su influencia se van a gestar.

${ }^{26}$ W. Weisbach, Op. cit., p. 136. Podemos englobar, dentro de esta tipología iconográfica la elevación al cielo del díptico Symmachi, por realizarse a través de dos de sus rasgos más definitorios: el contacto entre las figuras aladas y el divinizado y la ascensión en oblicuo.

${ }^{27}$ No es preciso incidir en las conexiones iconográficas, estilísticas y cronológicas existentes entre la Puerta del Perdón de San Isidoro de León y la Puerta Miègeville en el sur de la basílica de Saint Sernin de Toulouse. Remitimos al clásico trabajo de P. DESCHAMPS, "Etudes sur les sculptures des Sainte-Foy de Conques et de Saint-Sernin de Toulouse et leurs relation avec celles de Saint-Isidore de Leon et Saint- Jacques de Compostelle", Bulletin Monumental, C, 1941, pp. 235-264. Vid. también, M. DuRLIAT, "Les origines de la sculpture romane á Toulouse et á Moissac", $\mathrm{Ca}$ hiers de civilisatiom médiévale, XII, 1969, pp. 349-363; ID. La sculpture romane de la Route de Saint-Jacques. De Conques à Compostelle, Mont-de-Marsan, 1990. Para el análisis de la Puerta Miègeville de Toulouse vid. pp. 398410 y para la del Perdón de San Isidoro de León, pp. 385389. Recientemente M. POZA YAGÜE, Op. cit., pp. 9-28, ofrece una revisión del conjunto esculpido leonés, desde un punto de vista contrario a la tendencia historiográfica tradicional, sobre todo en cuestiones relativas al origen y cronología de la fachada. Así, la autora considera que "todos los elementos y particularidades iconográficas de los tímpanos legionenses que se hacían derivar de la Porte Miègeville (ca. 1115 ) desde antiguo (...) tendrían su origen primero en estas portadas hispanas. Desde ahí habría partido el influjo hacia la tolosana, y no al contrario".

${ }^{28}$ W. WeISBACH, Op. cit., p. 136.
Tampoco es extraño, según venimos afirmando, que los grandes centros artísticos de finales del siglo XI y principios del siglo XII, vinculados en muchos casos a la órbita de la Reforma Gregoriana, tuvieran acceso a obras clásicas y tardoantiguas de primera categoría. Sobradamente conocido es el caso de los marfiles de tradición imperial romana; ya fuesen dípticos consulares o simples placas de incrustación ${ }^{29}$. Así, hemos visto como el díptico de Symmachi o, en última instancia, uno de similares características, pudo ser utilizado como motivo de inspiración para la portada de Toulouse y en derivación para la del Perdón de San Isidoro de León.

Este hecho debe ser tenido muy en cuenta a la hora de indagar sobre el origen de las comentadas representaciones figuradas, pues como se ha venido considerando, la portada tolosana es una de las primeras manifestaciones monumentales esculpidas tras el resurgir de esta técnica posteriormente a la caída del imperio romano, donde la imagen retoma toda su capacidad de persuasión y de transmisión de ideas ${ }^{30}$. El hecho que nos interesa señalar, es el importante papel jugado por los trabajos eborarios de tradición clásica, en la formación del estilo escultórico románico y en última instancia, la dependencia que con respecto a los trabajos suntuarios, se ha hecho de la portada leonesa.

Ello nos lleva a pensar un posible origen común no sólo para la iconografía, sino también para el estilo de las portadas de Miègeville y San Isidoro: los trabajos ebúrneos del mundo antiguo $^{31}$.

${ }^{29}$ M. DuRLiAT,'Les origines...,", p. 360.

${ }^{30}$ Esta es la idea defendida por X. BARRAL I Altet, "Propaganda eclesiástica y poder feudal. El orden del mundo en las fachadas románicas", Propaganda y Poder. Congreso Peninsular de História da Arte, Lisboa, 1999, pp. 5770 , en concreto p. 59, donde entiende la fachada esculpida románica como el resurgir de un medio de expresión ideológica que tan sólo es equiparable al que se había alcanzado en la Antigüedad. La misma opinión tiene M. A. CASTIÑEIRAS GONZÁLEZ, "La catedral románica: tipología arquitectónica y narración visual", Santiago, la Catedral y la memoria del arte, Santiago de Compostela, 2000, pp. 39-96, especialmente p. 64, donde considera que la recuperación de la escultura como instrumento de comunicación durante el periodo románico, debe atribuirse en parte al interés que por las producciones artísticas de la Antigüedad mostraron los centros vinculados a la Reforma Gregoriana.

${ }^{31}$ Interesa destacar aquí, cómo este gran centro de la órbita cluniacense que fue Saint-Sernin de Toulouse, parece haber tenido un papel fundamental en el desarrollo de la 
La idea resulta interesante si atendemos a las afirmaciones que Serafín Moralejo hace sobre el estilo del denominado Maestro de Platerías $^{32}$ de la catedral de Santiago: "las fuentes

escultura monumental románica. Sin embargo más interesante resulta la filiación que de manera reiterada se ha hecho entre el estilo escultórico desarrollado a finales del siglo XI en la basílica tolosana y los trabajos en marfil.

Sobradamente conocidas resultan las placas incrustadas en el deambulatorio de Saint Sernin, donde fueron representadas la figura de Cristo en Majestad acompañada de ángeles serafines y querubines, así como de los apóstoles; todos ellos con idénticas características: rostros imberbes, de fuerte mentón, que en un futuro devendrían en uno de los rasgos definitorios de la escultura tolosana y por irradiación hispana, cabellera fuertemente ornamentada, etc. Todo ello deriva de los trabajos en marfil, tal y como vemos en el volumen marcado pero suave, a través del cual la luz se desliza, típico de los trabajos ebúrneos, interés desmesurado por la captación de pliegues, elemento habitual de los trabajos realizados en materiales blandos y fáciles de trabajar. Sobre la filiación de estas obras con los modelos antiguos, en concreto con los dípticos consulares, ver: H. FOCILLON, La escultura románica: investigaciones sobre la historia de las formas, Madrid, 1987, pp. 206-207, donde propone idéntico origen para estas obras, pero también para otras de similar importancia; como los relieves de los machones y placas del claustro de Moissac y la escultura de "rostros hinchados", tal y como él la define, refiriéndose al estilo de buena parte de la escultura de las portadas del transepto de la catedral de Santiago y las de San Isidoro de León. Sobre el claustro de Moissac, véase: Q. CAZES Y M. SELLES, Le cloître de Moissac, Bordeaux, 2001, en especial pp. 23-24. Además, a todo lo dicho debemos añadir la atribución al conocido Guilduino de parte de esta escultura, no sólo de estas placas del deambulatorio, sino también de la mesa de altar de la basílica (1096), derivada una vez más de los trabajos del arte antiguo y paleocristiano, tal y como señala Durliat, quién conecta su obra con algunas de las mejores muestras del trabajo eborario cristiano primitivo, como por ejemplo la arqueta de Brescia; vid. al respecto, M. DURLIAT, La sculputure romane..., pp. 106-107. El propio Durliat, también buscó dependencia de los sarcófagos cristianoprimitivos del suroeste de la Galia: ID. "Les origines de la sculpture...", p. 353. Por su parte, S. MorAlEJO, "Modelo, copia y originalidad...", p. 96, considera fundamental el papel jugado por Bernardo Guilduino y las artes en marfil clásicas, para el ambiente artístico en el que se formó el llamado Maestro de Platerías de la sede compostelana. Algunos detalles de las esculturas de la Portada del Perdón apoyan esta idea. Así, frecuentemente se han comparado los pequeños motivos florales a modo de rosáceas que flanquean desde los ángulos las placas tolosanas, con el mismo motivo que hayamos en los ángulos superiores de las placas de San Pedro y San Pablo de la portada leonesa y los que decoran los relieves de los machones del claustro de Moissac (fig. 8): ID. La sculpture romane..., p. 388.

${ }^{32}$ No es preciso incidir en la problemática del término "maestro" y su uso en la atribución de obras de arte altomedievales. Evidentemente con este concepto nos referimos no a una persona concreta y a un trabajo de una sola mano, sino a una tendencia estética de rasgos estilísticos comunes y asimilables bajo una denominación común, que en este caso es la de "Maestro de Platerías". Sobre el citado maestro, vid. S. MoraleJo, "La primitiva fachada norte de la Catedral de Santiago", Patrimonio artístico..., vol. I, pp. 21-46, en de su arte están poco claras. Se ha insistido en la influencia de los marfiles (...)", "hay que suponer a Esteban (el Maestro de Platerías) formándose en una región en donde la huella romana fue considerable" 33 .

A estos elementos habituales dentro de las artes sunturarias de la Antigüedad tardía, debemos sumar otros de diversa índole, utilizados frecuentemente por los escultores de los que venimos hablando. Nos referimos a los llamados tituli $^{34}$. Utilizados nuevamente en todo el arte de la Alta y Plena Edad Media, se convertirán en auténticas explanationes ${ }^{35}$ a las que de manera frecuente se les ha dotado de intencionalidad pedagógica y moralizante y que conseguían mediante la imagen transmitir al sujeto no cultivado las verdades, preceptos e ideas cristianos ${ }^{36}$.

concreto p. 44 donde da nombre propio a este maestro: Esteban, que se caracterizaría por el uso de "tipos faciales de carrillos hinchados, ojos abultados, labios gruesos, así como de la forma de tallar el cabello en mechones estrangulados cayendo las puntas en efectos rítmicos".

33 Ibidem, p. 45. Afirmaciones como la que nos ofrece el profesor Moralejo, relacionando las esculturas del Maestro de Platerías con las obras de arte clásicas, nos permiten advertir un origen común también para el estilo tolosano de Miègeville y el de las esculturas de la Puerta del Perdón de San Isidoro, emparentadas indisolublemente con la escultura santiaguesa. Igualmente, M. A. CASTIÑEIRAS GonZÁLEZ, Atlas de la catedral románica de Santiago. Narración visual e interpretación artística, Santiago de Compostela, 2004, (Edición digital, CdRom), afirma que el maestro de Platerías es "heredero del gusto por la Antigüedad del Maestro de Frómista-Jaca"; ID. "Un adro para un bispo: modelos e intencions na fachada de Praterías", Sémata, Cultura, Poder y mecenazgo, 10, Santiago de Compostela, 1998, pp. 231264.

${ }^{34}$ La definición que nos ofrece Grabar a este respecto sigue siendo hoy perfectamente útil: "explican en estilo florido y directo las escenas representadas", A. GRABAR, Las vias de la creación..., en particular p. 174.

${ }^{35}$ Tal y como nos indica V. GARCÍA LOBO, "Las inscripciones medievales de San Isidoro de León. Un ensayo de Paleografía epigráfica medieval", Santo Martino de León. Ponencias del I Congreso Internacional sobre Santo Martino en el VIII Centenario de su obra literaria 1185-1985, León, 1987, pp. 373-397, en especial p. 385, las explanationes son: "inscripciones que acompañan a modo de explicación a escenas iconográficas o pictóricas".

${ }^{36}$ De nuevo debemos remontarnos a la Antigüedad para poder rastrear el origen de este recurso literario, ya que tradicionalmente ha sido considerado una readaptación cristiana del viejo lema pagano del ut pictura poesis: J. JAQUES PI, La estética del románico y el gótico, Madrid, 2003 , p. 52. Sin embargo debemos señalar una vez más la sobrelectura que de este fenómeno se ha hecho, sobre todo respaldada por el continuo uso de los conocidos textos de Gregorio Magno (540-604) y su afirmación "las pinturas están hechas para la instrucción de los iletrados, (...) no para ser veneradas, sino para educar las mentes de los 
En el caso que nos ocupa, observamos la existencia de un tituli que por su longitud debemos considerar explanatio y donde se explica mediante el siguiente texto la Ascensión de la figura de Cristo a los Cielos:

\section{(Cruz) ASCENDO AD PATREM MEVM ET PATREM VESTRVUM ${ }^{37}$}

Este instrumento de explicación iconográfica que tradicionalmente se liga al arte tardo Antiguo, debe ser visto como un intento por parte del mentor del programa, de clarificar la escena y convertir su iconografía, sino en didáctica al menos en comprensible para el espectador a través de la combinación entre texto e imagen. Fenómeno que tradicionalmente se ha venido considerando como rasgo distintivo del arte de la Reforma Gregoriana ${ }^{38}$.

\section{LAS FIGURAS APOSTÓLICAS Y LA ES- CULTURA CRISTIANO-PRIMITIVA.}

Tal y como hemos comentado, flaqueando el tímpano de la fachada del Perdón, se dispusieron dos esculturas empotradas de gran formato, en las que se representaron las figuras apostólicas de San Pablo, a la izquierda y San Pedro, en el lado derecho ${ }^{39}$. En este apartado

ignorantes", vid. al respecto M. BARASCH, Teorías del Arte. De Platón a Winckelmann, Madrid, 1999, en especial pp. 63-65 donde aborda el problema del valor didáctico y educacional del arte medieval.

${ }^{37} \mathrm{La}$ traducción para este texto es la siguiente: "Me elevo a Dios que es mi padre y el vuestro". La tipología y características de esta letra carolina hacen posible situarla a mediados del siglo XII. Agradezco al profesor D. Vicente García Lobo la información prestada en lo relativo a este epígrafe, aún a pesar de encontrarse en este momento dicha inscripción en fase de estudio y cuyos resultados aún no han sido publicados. Sobre ella también se pronuncia M. DURLIAT, Le sculpture romane de la route..., p. 387.

${ }^{38}$ W. SAUERLÄNDER, "Façade ou façades romanes?", Cahiers de Civilisation Médiévale, XXXIV, 1, 1991, pp. 393-401. Del propio Sauerländer toma la idea; D. OCÓN AlONSO, "El sello de Dios...", concretamente pp. 93-94, al considerar que la combinación de tituli e imágenes, no sólo tenía su mejor exponente en las grandes basílicas tardoantiguas de Roma y Milán, sino que su traspaso y continuidad en el ámbito altomedieval se debió a su uso por parte de los artistas carolingios. Sobre el mismo tema M. A. CASTIÑEIRAS GONZÁLEZ, El calendario medieval hispano (s. XI$X I V)$, Salamanca, 1996, pp. 56-60, quién se centra concretamente en los tituli de las pinturas del Panteón Real de San Isidoro de León.

39 E. FERnÁNDEZ GONZÁLeZ, San Isidoro de León, Madrid, 1991, p. 28, identifica estas figuras como Pedro y Pablo y las relaciona con las del claustro de Moissac y las de la girola de Tolouse, sobre todo por el uso de las rosetas de la parte superior, apuntando también su posible relación con analizaremos algunas representaciones que nos permitan comprender el porqué de la elección de estos dos personajes y su colocación en un lugar tan destacado de la fachada.

Sabemos, a través de los ejemplos conservados en las portadas románicas, que la colocación de figuras en pareja flanqueando los accesos a los templos fue cuanto menos frecuente. Así, para poder concluir el modelo o fórmula artística que inspiró a los artífices de la fachada leonesa, nos tenemos que remitir, a las primeras experiencias escultóricas dentro de la plástica monumental.

Para el caso francés y siguiendo la teoría defendida por M. Durliat, fue el conjunto esculpido de Marcilhac (fig. 9), que él data en una fecha ligeramente anterior a 1090, el que daría origen a este tipo de composición escultórica que tanta fortuna tendría tanto en suelo hispano como francés. En este caso concreto la imagen central de Cristo entronizado aparecería flanqueada por sendas placas rectangulares, en las que fueron esculpidas bajo arco de medio punto las imágenes de Pedro y Pablo ${ }^{40}$.

El siguiente edificio en seguir este sistema compositivo, fue la propia basílica de Saint Sernin de Toulouse y más concretamente la llamada Porte des Comtes, donde encontramos de nuevo idéntica composición. Flanqueando el acceso bíforo de la fachada, se colocaron dos figuras talladas en sendas lajas de piedra rectangulares y que de nuevo aparecían dignificadas

obras ebúrneas, en concreto la arqueta de los marfiles del Museo de la Colegiata. La teoría de la autora nos parece acertada, pues establece un nexo de unión entre obras de las que se ha señalado como uno de los rasgos comunes, su fuerte relación con los trabajos en marfil. Vid. también, M. DURLIAT, La Sculpture..., p. 388.

${ }^{40}$ El caso de las esculturas de Marcilhac es verdaderamente significativo para comprender el juego compositivo de dos figuras independientes flanqueando una escena o tímpano central. Sin embargo, para el caso francés supuso el nacimiento de otra de las grandes soluciones compositivas del románico galo, pues la ubicación de figuras individuales bajo arco de medio punto habría de tener un éxito rotundo, atestiguado por las esculturas empotradas en el deambulatorio de Saint Sernin de Toulouse, las esculpidas en los machones del claustro de Moissac o las posteriores de la Sala Capitular de Saint Etienne de Toulouse.

Sobre la portada de Marcilhac véase M. DuRLiAT, "L'aparition du grand portail roman historié dans le Midi de la France et le Nord de 1'Espagne", Les Cahiers de SaintMichel de Cuxa, 8, 1977, pp. 7-24, en concreto p. 16. 
por el consabido esquema de arco de medio punto $^{41}$.

Sin embargo, el modelo en el que probablemente se inspiró el artífice de la fachada del Perdón de San Isidoro de León, pudo estar en otra serie de repertorios más cercanos, al menos desde un punto de vista geográfico. Nos estamos refiriendo a la fachada sur de la catedral de $\mathrm{Jaca}^{42}$, donde de nuevo parece ser que se repitió este mismo sistema compositivo.

De la misma manera y siguiendo siempre la sucesión cronológica aceptada tradicionalmente para el desarrollo de los trabajos escultóricos en los centros de finales del siglo XI y principios del XII, sabemos que una decena de años después de la construcción de la Puerta des Comtes, concretamente en 1103, se iniciaban los trabajos en las portadas del transepto de la catedral de Santiago de Compostela ${ }^{43}$.

En sus fachadas, según narra el Codex Calixtinus, se encontraban flanqueando el acceso al edificio las figuras de Pedro y Pablo, así como las de Juan y Santiago:

Arriba, en las jambas, se ven cuatro apóstoles que llevan sendos libros en la mano izquierda y con las diestras levantadas bendicen a los que entran en la iglesia: Pedro está en la entrada a la izquierda, a la parte derecha, Pablo a la izquierda; y en la entrada derecha están

-

${ }^{41}$ La fachada de Comtes, fechada tradicionalmente en torno al año 1090, fue una de las primeras, junto con la de Marcilhac, en utilizar esta distribución espacial de las figuras. En este caso concreto y siguiendo a Durliat, se trataría de dos de los discípulos de San Saturnino, los llamados Papoul y Honest, que flanquearían la propia figura del mártir, que de idéntica manera se coloca en la enjuta de los dos arcos de acceso al templo, vid. M. Durliat, "L'apparition...", p. 11.

${ }^{42}$ Para el estudioso francés, la fecha del portal de la catedral de Jaca sería un poco posterior al año 1100: M. DURLIAT, "L'apparition...", p. 23.

${ }^{43}$ En el caso concreto de la fachada de Platerías, según nos dice la inscripción de la jamba de acceso al templo, fue iniciada el 11 de julio de 1103. Las obras durarían hasta el año 1111. Sobre las cuestiones cronológicas de la escultura de las fachadas del crucero de la sede compostelana, vid. M. A. CASTiÑEIRAS GONZÁlez, "La meta del Camino: la catedral de Santiago de Compostela en tiempos de Diego Gelmírez", Los caminos de Santiago. Arte, Historia y Literatura. (María del Carmen Lacarra Ducay, coord.), Zaragoza, 2005, pp. 213-252, en concreto p. 228 y pp. 335-336.

\section{el apóstol Juan a la derecha y Santiago a la izquierda ${ }^{44}$.}

En este sentido parece claro que el modelo compositivo de ubicar dos personajes parejos en los accesos de los templos ya estaba perfectamente asentado en los primeros años del siglo XII, no sólo en suelo francés, sino también hispano. Así parecen atestiguarlo otra serie de fachadas donde de igual manera se repite idéntica distribución.

Sin embargo, el modelo directo en el que se pudo inspirar la distribución compositiva, que no estilística, de las figuras flanqueando el acceso al edificio de la Puerta del Perdón, debe buscarse en la otra gran portada de la basílica legionense, la del Cordero. Allí, de nuevo flanqueando el tímpano de acceso al edificio, fueron colocadas las esculturas del santo al que se dedicó la iglesia románica: San Isidoro, haciendo pareja con otra escultura que ha sido identificada como San Pelayo o incluso a veces como San Vicente ${ }^{45}$.

${ }^{44}$ Liber Sancti Jacobi “Codex Calixtinus”, Traducción de A. Moralejo, C. Torres y J. FeO, Pontevedra, 1992, p. 560 .

${ }^{45}$ La portada del Cordero ha sido objeto de numerosos estudios por parte de los especialistas. Se ha venido datando en torno a los primeros años del siglo XII. Véase al respecto, A. ViÑAYo GonZÁlez, Real Colegiata de San Isidoro. Historia, Arte y Vida, León, 1998, p. 52. Sobre la fachada en general, vid. E. FERNÁNDEZ GONZÁlEZ, San Isidoro de León..., en especial pp. 24-26. Para J. W. WiLliams, "Generationes Abrahae: iconografía de Reconquista en León”, El tímpano románico: imágenes, estructuras y audiencias, Santiago de Compostela, 2003, pp. 155-180, en particular pp. 173-174, la fachada del Cordero debería datarse cuanto menos en los años posteriores a la muerte de Alfonso VI $(\dagger 1109)$. Además apoya su teoría en una supuesta filiación y dependencia entre algunas de las figuras de la portada leonesa y la Puerta Miègeville de Saint Sernin de Toulouse, no anterior a los años 1110-1115. Por el contrario M. POZA YAGÜE, "Entre la tradición...", p. 19, propone unas fechas muy tempranas, al afirmar que fue Urraca la hija mayor de Fernando I y Sancha la promotora de esta comentada Puerta del Cordero, lo que le lleva a datarla cronológicamente en torno al año 1101, año en el que Urraca muere. Según T. MARTIN, "Un nuevo contexto para el tímpano de la Portada del Cordero en San Isidoro de León", El tímpano románico..., pp. 183-205, en concreto pp. 193-198, la Portada del Cordero y los capiteles de los ábsides pertenecen a las primeras campañas escultóricas del edificio patrocinadas por la infanta Urraca (1095-1101). Por su parte, M. A. CASTIÑEIRAS GONZÁlEZ, "La meta del Camino...", p. 237, defiende la fecha de 1115 como la más conveniente para la realización de dicha portada. Sin embargo, para nuestro cometido lo más interesante no es resolver si la portada es anterior o posterior a las fechas barajadas, pues lo realmente importante es que el modelo compositivo en lo relativo a las 
Llegados a este punto, parece claro que este sistema de composición del que forman parte las figuras de Pedro y Pablo de la portada del Perdón, era plenamente conocido y usado en los centros artísticos de finales del siglo XI y comienzos del XII. Y que en el caso de San Isidoro de León quedó plenamente asimilado en sus dos fachadas monumentales; tal y como sugiere la colocación de San Isidoro y Pelayo en la puerta meridional y San Pablo y San Pedro en el hastial sur.

Sin embargo, si bien el porqué de su ubicación física en la fachada parece claro, no lo es tanto en lo referente a la elección iconográfica de las comentadas figuras. Y si lo es, merece la pena indagar en las fuentes artísticas y literarias a la que los escultores de nuestra portada tuvieron acceso.

Ya hemos mencionado anteriormente la portada de Marcilhac, como ejemplo temprano del uso de la escultura en fachada monumental. Allí y en torno a 1090 se habían colocado las figuras de Pedro y Pablo flanqueando un Cristo en Magestad ${ }^{46}$.

Del mismo modo, según nos dice el Codex Calixtino, las figuras de Pedro y Pablo volverían a ocupar el acceso al templo compostelano, en una fecha no superior a los años 11111112, según nos indica Serafín Moralejo. En una cronología muy próxima a esta, parece que estaba finalizada la fachada que tradicionalmente la historiografía ha supuesto como antecedente directo de la fachada del Perdón: la llamada Puerta de Miègeville de Saint Sernin de Toulou$\mathrm{se}^{47}$. También aquí encontramos de nuevo, en

figuras en pareja en los accesos, tiene su origen en esta serie de fachadas esculpidas en los inicios del siglo XII y que el taller leonés lo supo sintetizar de manera clara en sus dos fachadas.

${ }^{46}$ Véase la nota 40 del presente trabajo.

${ }^{47}$ La fachada Miègeville de Saint Sernin de Toulouse, ha recibido diferentes dataciones, generalmente dentro del primer decenio del siglo XII. Tal y como propone M. DURLIAT, La sculpture romane..., en especial p. 402. Más exacto se mostraba el estudioso francés al datar la portada antes del año 1118 , fecha en la que muere el canónigo de la iglesia Raymond Gayrard y en la que parece ser, los colaterales del transepto ya estaban terminados. Estos y otros datos le llevaron a afirmar: "L'ouvrage fut terminé par des sculpteurs en rapport avec Compostelle, sans doute entre 11101115". Anteriormente H. FOCILLON, La escultura románica..., pp. 146-148, databa la portada siguiendo la misma noticia de la muerte del canónigo Gayrard, en el año 1118. Para M. A. CASTIÑEIRAS GONZÁLEZ, "La meta...", p. 238, la portada francesa dataría de esos mismos años 1110-1115, los laterales de la fachada, una pareja de apóstoles colocados a modo de protectores del acceso a la basílica ${ }^{48}$. Para comprender el porqué de esta insistencia en la exaltación de las figuras apostólicas y en el caso de León, en concreto la dualidad entre Pedro y Pablo, debemos recurrir a diversas fuentes.

Sabemos a través de las fuentes literarias que la misión apostólica estuvo dominada por las figuras de Pedro y Pablo, por lo que desde las primeras representaciones plásticas del arte cristiano, van a aparecer formando pareja ${ }^{49}$.

Es posible que esa dualidad entre ambos personajes y su gran éxito dentro de los programas románicos tenga su origen en el desarrollo que dicha iconografía tuvo dentro del arte paleocristiano. Así la encontramos en alguna de las más significativas obras de este primer arte cristiano, tal y como nos muestra la lámpara de aceite del Museo Arqueológico de Florencia, donde las figuras de Pedro, en la proa y Pablo, en la popa, aparecen dirigiendo la "Barca de la Iglesia" ${ }^{, 50}$.

De la misma manera y con idéntica frecuencia encontramos a los dos apóstoles representados en infinidad de ejemplos escultóricos adscritos al los primeros periodos del arte cristiano, donde la dualidad iconográfica de Pedro y Pablo servía de acompañamiento a otras temas como el crismón, Cristo o la orante. Sirvan a modo de ejemplo, entre los muchos existentes,

coincidiendo con las obras del transepto de Santiago de Compostela. Además llega a conectar algunas de las figuras de la Puerta de Saint Sernin, con las obras adjudicadas al llamado Maestro de la Transfiguración de la sede compostelana.

${ }^{48}$ M. DURLIAT, La sculpture romane..., pp. 405-407 ; ID. “L'apparition...”, p. 18.

Llamamos aquí la atención sobre una notable diferencia entre la fachada francesa y la leonesa; ya que mientras en el caso de León son Pedro y Pablo los que flanquean la entrada al templo, en el de su homónima francesa, son Pedro y Santiago los que ocupan ese mismo lugar. La razón y explicación ante esta diferencia la analizaremos más adelante.

49 Ello hizo que desde los primeros tiempos la iconografía cristiano primitiva fijase de manera clara los rasgos fisonómicos de estos apóstoles a través de la calvicie y barba larga y negra para Pablo y pelo y barba blancos en forma de collar para Pedro: M. ZIBAWI, "El auge del arte cristiano. Siglo IV", El arte paleocristiano. Visión y espacio. De los orígenes a Bizancio, Milán, 1998, pp. 109-182, particularmente p. 163. Este rasgo distintivo tan plástico gozaría de gran éxito en todo el arte medieval, e incluso posterior, tal y como bien es sabido.

$$
{ }^{50} \text { Ibidem, Op. cit., p. } 178 .
$$


el relieve de Aquileya donde las dos figuras fueron representadas frente a frente, el sarcófago hispano llamado de los "Apóstoles", donde fueron representados Pedro y Pablo en los extremos de la $\operatorname{cista}^{51}$ (fig. 10) y en idéntica línea temática el de Berja donde de nuevo encontramos la representación de la pareja apostólica ${ }^{52}$. Todos ellos seguidores de una misma línea ideológica que busca mediante la presencia de los apóstoles verificar y refrendar la verdad y principios cristianos, además de interceder como psicopompos del difunto ${ }^{53}$.

Sin embargo no solo la escultura monumental nos proporciona ejemplos de esta iconografía, ya que son muchas las piezas en las que la exaltación de la dualidad y unión ideológica entre ambas figuras apostólicas parece clara. Baste citar nuevamente un ejemplo en marfil. Se trata del díptico de Berlin, donde encontramos a Pedro y Pablo flanqueando la figura de Cristo, de alguna manera atestiguando su fidelidad, apoyo y obediencia hacia la figura de Jesús ${ }^{54} \mathrm{o}$ ya en pintura, el díptico de la Biblioteca Apostólica del Vaticano donde se representó, en cada

-

${ }^{51}$ Podemos considerar este sarcófago de los Apóstoles como cabeza de serie para la iconografía hispana, así como fundamental para el nacimiento y desarrollo del tema de los dos apóstoles, que tanta fortuna habría de tener en la escultura de sarcófagos paleocristianos y tal y como veremos, en la escultura románica. El sarcófago se encuentra en el Museo de la Necrópolis de Tarragona. Véase P. DE PALOL, Arte paleocristiano..., pp. 260-262.

${ }^{52}$ La pieza en cuestión se conserva en el Museo Arqueológico de Almería y a pesar de ser una obra salida de talleres romanos, podemos suponer su influencia dentro de la escultura paleocristiana española. Vid. Ibidem, pp. 130138. Parece claro que la colocación de los dos apóstoles en pareja dentro de la iconografía escultórica del arte paleocristiano hispano, deriva en gran parte del conocimiento de las producciones artísticas romanas; tal y como representa el sarcófago de la catacumba de Domitila (hoy en el Museo Pío Cristiano de la Ciudad del Vaticano): sobre él véase W. ZIBAWI, Op. cit., p.138.

${ }^{53}$ El hecho de incluir a santos mártires, obispos y demás personajes eclesiásticos, dentro de los sarcófagos, sepulcros y tumbas durante los siglos medievales, no hace otra cosa que la de continuar una tradición de raigambre paleocristiana, según la cual estos intercedían a favor del difunto. Sobre el tema vid. R. SÁNCHEZ AMEIJEIRAS, “¿Portada o relieve funerario? Una propuesta acerca de un tímpano leonés", Arte d'Occidente. Temi e metodi. Studi in onore di Angiola Maria Romanini, vol. I, Roma, 1999, pp. 519535, en especial p. 521

${ }^{54}$ El díptico de marfil se encuentra en el Staatliche $\mathrm{Mu}-$ seum de Berlin y destaca por su fuerte impronta helenística a pesar de su temática cristiana: W. ZIBAWI, Op. cit., p. 418, fig. 384 una de sus dos hojas, las figuras de Pedro y Pablo ${ }^{55}$.

Todos estos ejemplos, que sin duda podrían ser muchos más, sirven para demostrar dos cosas: en primer lugar la total frecuencia con que las parejas de apóstoles fueron representadas en la iconografía paleocristiana dentro de escenas de carácter funerario o en aquellas en la que se narraba la muerte de algún personaje, en muchas ocasiones Cristo y en segundo lugar; la fuerte tradición iconográfica que por estos momentos se estaba formando y que tendría grandes repercusiones en todo el arte posterior.

Sin embargo su uso, tanto en periodos antiguos como medievales, debe explicarse desde el punto de vista teológico, más que desde el artístico. Sabemos que durante el arte paleocristiano, la referencia y el modelo a seguir por parte del estamento religioso, estaba en el ideal de vida apostólica que habían difundido los primeros apóstoles ${ }^{56}$. Este ideal de vida apostólica convertía a los apóstoles en auténticos exempla a seguir en cuanto a seguidores del mandato, fe y palabras dictaminados por Cristo, lo que artística e iconográficamente se tradujo en el desarrollo y profusión de los apostolados dentro del edificio medieval.

El hecho de que desde Roma y desde otros centros secundarios como Cluny, se impulsase el seguimiento del ideal apostólico de vida religiosa comunitaria, acabó promoviendo la aparición de apostolados, dentro los programas escultóricos de las fachadas románicas. Hecho, que no tenía otro sentido que el de publicitar ese ideal monástico y clerical de la vida cristiana; además de ejemplificar y aludir en pleno siglo XII al comportamiento que los primeros discípulos de Cristo, es decir los apóstoles, habían tenido antes de la diáspora ${ }^{57}$.

-

55 Ibidem, p. 179

${ }^{56}$ H. TOUBERT, Op. cit., p. 154.

${ }^{57}$ Esta es la explicación que Serafín Moralejo proponía para el gran desarrollo de los apostolados dentro de la iconografía románica; vid. S. MORALEJO, "Arte del Camino de Santiago y Arte de peregrinación (ss. XI- XIII), Patrimonio Artístico..., II, pp. 137-144, concretamente p. 139.

El tema iconográfico del apostolado tuvo su gran desarrollo dentro de las primeras producciones artísticas cristianas. Su resurgir en los primeros años del siglo XII debe entenderse dentro de un contexto religioso dominado por los ideales de la Reforma Gregoriana. Sobradamente conocido es el éxito que el tema tuvo dentro de los claustros y fachadas del periodo románico, sin embargo tal y como apunta R. 
Sabemos, tal y como apunta Weisbach, que la gran portada de acceso a la abadía borgoñona de Cluny, tuvo en sus albanegas la representación de las figuras de San Pedro, San Pablo, Santiago el Mayor y San Juan, dos de ellos patrones de su iglesia ${ }^{58}$. Tras ella y de manera reiterativa aparecerían en cronologías próximas otra serie de ejemplos de similares características en diversas fachadas románicas. Este es el caso no sólo de la mencionada de Santiago de Compostela $^{59}$, donde tal y como hemos señalado presentaba en sus accesos las figuras de cuatro apóstoles, sino otras que encontramos en diferentes puntos, a veces sin ningún tipo de relación geográfica.

En Francia son significativos los casos de San Sernin de Toulouse y su Puerta Miègevi$1 e^{60}$, Saint-Gilles-du Gard ${ }^{61}$, Sant-Galles du Nord $^{62}$, Beaulieu ${ }^{63}$ y muy posiblemente Soui-

SÁNCHEZ AMEJEIRAS, "Una empresa olvidada del primer gótico hispano: la fachada de la sala capitular de la catedral de León", Archivo Español de Arte, 1996, pp. 389-406, en particular p. 404, notas 38 y 39, este ideal de vita communis o vita apostolica tan difundido por la Regla de San Benito y adoptado por la Reforma Gregoriana, se encontraría incluso entre los temas predilectos de la última escultura románica, tal y como observamos en las figuras de Pedro y Pablo que originariamente ocupaban la Sala Capitular de la catedral de León, en torno al año 1200 .

${ }^{58}$ W. WeISBACH, Op. cit., pp. 141-142. Esta noticia parece totalmente verosímil a juzgar por los restos que hoy conservamos de la fachada occidental de Cluny. Tan sólo la figura de San Pedro resistió a la labor destructora revolucionaria. Sobre esta pieza vid. J. K. CONANT, Cluny. Les églises..., especialmente pp. 104. También M. DuRliat, "L'apparition du grand...", p. 20, recoge la existencia de la pieza y la considera perteneciente a los laterales del gran portal de Cluny.

${ }^{59}$ W. WeISBACH, Op. cit., p. 112.

${ }^{60}$ En ella, insistimos, encontramos flanqueando la portada las figuras de Pedro y Santiago, realizadas en una escultura de marcado volumen y rotundidad monumental, W. WeISBACH, Op. cit., p. 137.

${ }^{61}$ En este caso las figuras apostólicas se hallan colocadas en las jambas de la portada central, Ibidem, pp. 142; vid. M. F. HEARN, Romanesque sculpture. The revival of Monumental Stone Sculpture in the Eleventh and Twelfth Centuries, Ithaca, New York, 1985, en particular pp. 204-207.

${ }^{62}$ Actualmente podemos identificar a Pedro, Pablo y Juan, a través de las inscripciones que les acompañan. Además cabe suponer que el cuarto apóstol fuera Santiago el Mayor, si seguimos la elección iconográfica que habitualmente se sigue en las fachadas románicas conservadas: W. WEISBACH, Op. cit., p. 169.

${ }^{63}$ En el caso de la fachada de Beaulieu, las figuras conservadas son las de Pedro y Pablo, ubicadas a cada lado del pórtico, en pie y sin encuadramiento; Ibidem, p. 102. llac ${ }^{64}$, entre otros. Debemos destacar como rasgo común entre estos ejemplos, la total conexión y continua relación que mantuvieron con la abadía de Cluny.

Dentro de los ejemplos hispanos, además de este que nos ocupa de San Isidoro de León, y el mencionado de la catedral de Santiago de Compostela, debemos aludir a otro ejemplo aunque si bien éste es ciertamente dudoso. Nos referimos al posible San Pedro del restituido portal de la fachada sur de la catedral de Jaca donde fue colocado, en la albanega superior derecha, lo que Serafín Moralejo ha descrito como un "apóstol o santo" y que porta un libro como atributo $^{65}$. Deducimos, a través de la lectura del paramento, bastante movido, que en la albanega izquierda existió otra figura, que del mismo modo que los ejemplos franceses aducidos, flanqueaban el acceso al templo.

De esta manera se presentaba a los ojos del espectador el ideal de la vita communis que la Reforma Gregoriana estaba difundiendo durante este periodo y a través de esta iconografía se aludía, con la presencia de Pedro y Pablo, a la abadía difusora de esas ideas: Cluny, y por extensión a la ciudad donde esos dos santos eran venerados, es decir, Roma ${ }^{66}$.

Ello podría establecer un precedente, que explicase la presencia de los dos santos en la portada del Perdón de San Isidoro de León, donde Pablo se nos muestra nimbado, con un

-

${ }^{64}$ Lamentablemente tan sólo conservamos la figura de Pedro, segundo patrono de Cluny, pero llama la atención en este caso las similitudes formales, que no estilísticas, que presenta con el apóstol Pablo de San Isidoro de León, pues al igual que éste, aparece con un libro en la mano izquierda y el antebrazo de la derecha levantado con la palma de la mano abierta en actitud salutatoria. Debemos, no obstante, ser cautos ante el caso de Souillac, pues tan sólo conservamos una de las supuestas cuatro figuras y ningún indicio más tenemos sobre la posible existencia de este supuesto conjunto de apóstoles; Ibidem, p. 112.

${ }^{65}$ S. MoRALEJO, "La sculpture romane de la cathédrale de Jaca. État des questions", Patrimonio artístico..., vol. I, pp. 141-160, en particular pp. 157-158. La identificación que hace el autor viene abalada por la dedicación del templo a San Pedro. No obstante, lo que parece claro es que la temprana escultura de la seo jaquesa tenía total conocimiento del sistema compositivo de portada central flanqueada por dos figuras en las albanegas que desde la portada de Comtes en Toulouse y la de Morcilhac, habría de convertirse en un auténtico hito en la decoración de fachadas románicas.

${ }^{66}$ M. POZA YAGÜE, Op. cit., p. 20 considera que la introducción de las figuras de Pedro y Pablo en la fachada leonesa, se debe a su consideración como pilares de la iglesia de Roma, además de patronos de Cluny. 
rico libro en la mano y gesto de salutación dirigido al fiel que accede al templo; mientras que Pedro muestra las llaves del paraíso ${ }^{67}$ y báculo, auténtico signo de su rango eclesiástico ${ }^{68}$.

Siguiendo con la línea de lo explicado hasta aquí, la mayoría de los ejemplos señalados presentan no sólo la dualidad de dos figuras apostólicas, sino que en ocasiones llegaron a ser cuatro, tal y como vimos en el caso de Cluny, Toulouse y Santiago de Compostela.

En el caso de San Isidoro de León la tarea se complica ante la total reestructuración que sufrió en época moderna el brazo norte del transepto, lugar en el que lógicamente habrían de estar colocadas las otras dos figuras apostólicas.

Hoy en día, en el brazo norte del transepto, permanece in situ una portada de doble rosca, cuatro capiteles ornamentados y un tímpano vacío. Según las teorías más recientes, todas ellas seguidoras de lo afirmado por G. Gaillard ${ }^{69}$

${ }^{67}$ El atributo iconográfico de las llaves para Pedro sigue de manera rigurosa la iconografía medieval, que desde el siglo XI se conocía en el arte creado en San Isidoro de León. Baste citar el caso del San Pedro de la caja ebúrnea de San Juan Bautista y San Pelayo de 1059 donde el apóstol aparece con unas llaves que a modo de caligrama forma su nombre $\mathrm{P}, \mathrm{E}, \mathrm{T}, \mathrm{V}$, un rasgo claramente emparentado con las fuentes del arte tardoantiguo cristiano, tal y como apunta J. Bousquet y que incide en el sustrato antiguo de muchas de las producciones románicas de los talleres leoneses: J. BOUSQUET, "Encore un motif roman composé de lettres: les clefs de Saint Pierre, ses origines ottoniennes et paléochrétiennes", Les Cahiers de Saint-Michel de Cuxa, XII, 1981, pp. 29-48, en especial p. 30.

${ }^{68}$ Es realmente interesante observar como en el caso de la figura de Pedro el rango eclesial está mucho más enfatizado que en el de Pablo. San Pedro viste casulla ornamentada a través de filigrana de motivos vegetales incisos en la piedra. Porta además de su atributo habitual, un báculo de remate curvo, típico papal y que le hacen inconfundible hasta el punto de que el lapicida obvio la labra de su nombre, hecho que no ocurre en la figura de Pablo, en cuya base leemos perfectamente PAVLVS. Este hecho introduce una vez más la portada isidoriana en la corriente ideológica gregoriana que considera a Pedro como jefe de la iglesia, como primado tras la muerte y resurrección de Cristo. Debemos señalar además, que la aparición de Pablo con el libro y Pedro con las llaves entronca tal y como señala M. Melero, con la tradición iconográfica de la Traditio Legis. Sobre este tema vid.: M. MELERo MoneO, "El tímpano de la iglesia de Sant Pol de San Joan de les Abadesses y la traditio legis", Anuario del Departamento de Historia y Teoría del Arte, V, 1993, pp. 19-29, especialmente pp. 2223, nota 15 .

${ }^{69}$ G. GAILLARD, Les débuts de la sculpture romane espagnole. León-Jaca-Compostelle, Paris, 1938, pp. 82-83, el y M. Durliat ${ }^{70}$, es posible que la fachada norte de la basílica de San Isidoro de León hubiese tenido en origen otra pareja de santos o apóstoles flanqueando el acceso al templo. Así Williams consideraba que el relieve de San Juan, actualmente conservado en el Museo de León, procedió en origen del transepto norte de la iglesia y por lo tanto se deduce que ocupó un lugar similar al que tienen en el acceso sur las figuras de Pedro y Pablo ${ }^{71}$.

De esta manera parece que las dos fachadas esculpidas en los cierres de los brazos del transepto de San Isidoro de León, incluían el edificio dentro del desarrollo escultórico e iconográfico que por esto momentos se estaba produciendo en algunos de los centros del panorama artístico de la primera mitad del siglo XII.

Así, al igual que los sarcófagos paleocristianos donde las figuras apostólicas evocaban el espíritu de la vida en común entre los fieles de la cristiandad y eran testigos de los sucesos relativos a la vida de Cristo; las monumentales figuras románicas de Pedro y Pablo, servían para enmarcar y complementar los sucesos narrados en el tímpano de la puerta. En él, Pedro se nos muestra no tanto como apóstol, sino como pontífice, aludiendo no al rango que había tenido en vida de Cristo, sino al que adquirió una vez muerto y resucitado éste, cuando al ascender al cielo nombró un gobernante en la tierra; momento en el que San Pedro se convirtió en el primer papa ${ }^{72}$.

Del mismo modo San Pablo aparece aquí desenvolviendo el papel que se le había otorga-

autor identifica, aunque con dudas, la escultura del Museo de León como San Pelayo.

${ }^{70}$ M. DURLIAT, La sculpture romane..., pp. 388-389, consideraba que tanto la postura de tres cuartos, el tamaño, la tendencia estilística y la vocación por el bulto redondo y otra serie de similitudes con las figuras de la fachada sur, le permitían sin problemas pertenecer al desaparecido portal norte de la Colegiata. Así mismo databa la pieza del Museo de León en una fecha no posterior al 1125.

71 J. W. WILliams, "Relief of Saint (John?)", The Art of Medieval Spain a. d. 500-1200, New York, 1993, ficha catalográfica $n^{\circ} 89$, pp. 209-210. Más recientemente M. POZA YAGÜE, $O p$. cit., p. 20, se sumaba a esta teoría, apuntando además la posibilidad de una identificación del personaje con el que el comentado San Juan haría pareja. Para la autora se trataría de la figura de Santiago.

${ }^{72}$ Sobre la figura de Pedro como gobernante en la tierra en relación con los ciclos de la Traditio Legis, vid. M. Melero MoneO, Op. cit., p. 25, donde además resalta su significado en relación con la Querella de las Investiduras y la Reforma Gregoriana. 
do: ser el apóstol por excelencia de la fe. Mediante su presencia se convertía en auténtico testigo terrestre de los sucesos acontecidos en el tímpano: es decir crucifixión, entierro y resurrección, todos ellos de fuerte carácter sobrenatural y que quedaban así refrendados por un ser terrenal que atestiguaba la fe en el Cristo resucitado representado en la placa derecha de las tres que configuran el tímpano leonés ${ }^{73}$.

\section{NUEVOS DATOS PARA LA LECTURA DE LA PORTADA: A PROPÓSITO DE UN RE- LIEVE PERDIDO.}

En el año 1985 el profesor Serafín Moralejo publicaba un artículo titulado "La imagen arquitectónica de la catedral de Santiago", en el cual realizaba una lectura iconográfica e iconológica de la conocida estructura occidental de la catedral gallega ${ }^{74}$. Sin embargo, su lectura no sólo se detenía en justificar la temática y distribución de los elementos escultóricos, sino que iba más allá al someter a lectura iconográfica los elementos arquitectónicos. La lectura "en altura" que proponía ${ }^{75}$, sirvió de punto de parti-

73 Esta es la explicación que da S. MoRALEJO, "El claustro de Silos y el arte de los caminos de peregrinación", El románico en Silos. IX Centenario de la consagración de la iglesia y el claustro, Burgos, 1989, pp. 203- 223, particularmente p. 215 , nota 45 , para justificar la inclusión de la figura de Pablo en el relieve que narra el episodio de la Duda de Santo Tomás.

${ }^{74} \mathrm{~S}$. MORALEJO, "La imagen arquitectónica de la catedral de Santiago de Compostela", Atti del Convengo Internazionale di Studi: Il pellegrinatio a Santiago de Compostela e la letteratura jacopea, Perugia, 1985, pp. 37-61, en reedición Patrimonio artístico..., vol. I, pp. 237-246. Especialmente pp. 242-244 donde somete dicho conjunto a una "lectura en altura".

${ }^{75}$ Entendía que los tres niveles del macizo occidental que cerraba el buque catedralicio de Santiago de Compostela podían someterse a una interpretación simbólica coherente, según la cual existía una idea rectora en el conjunto de exaltar la Segunda Venida, Juicio Final y posterior Gloria de la Jerusalén Celeste a partir de las visiones de Mateo. Todo ello expresado a través de la escultura, pero en total complementación con la arquitectura. De esta manera lo mundano o terrestre quedaría representado por la llamada cripta o iglesia vieja, símbolo de la Tierra. El piso intermedio sería una representación de las puertas de la gloria, sintetizadas a través de los trabajos en escultura y arquitectura; y finalmente el cielo de la gloria, ubicado en la galería de la parte alta del pórtico donde el Agnus Dei esculpido en la clave de la bóveda, evocaban la salvación eterna. Idéntica lectura hace M. A. CAstiñeiras GonZÁlez, El Pórtico de la Gloria, Madrid, 1999, pp. 51-55. Interesante es la postura de W. WeisBaCH, Op. cit., p. 135 quién analiza el caso del Pórtico de la Gloria considerándolo dentro del conjunto de obras de carácter penitencial, salvífico y mortuorio de algunos de los programas iconográficos del ámbito de Cluny. El autor considera que en el Pórtico de la Gloria se da para otras muchas interpretaciones de los programas esculpidos en las fachadas románicas, no en vano era un recurso sobradamente conocido en las experiencias artísticas de la escultura de los edificios galos ${ }^{76}$. Así, baste con citar el conocido grupo de los edificios del Poitou ${ }^{77}$, entre los cuales destacan las grandes fachadas telón de la iglesia de Saint-Pierre de Angoulême o de Notre Dame-la-Grande de Poitiers $^{78}$, donde la escultura se distribuye de tal manera que induce a una lectura iconográfica de abajo hacia arriba a través de diversos elementos escultóricos y también arquitectónicos, tales como arcos ciegos, columnas, vanos y rosetones.

Teniendo en cuenta este sistema de análisis artístico, proponemos indagar detenidamente en algunos elementos llamativos y en otros no tan evidentes de la fachada del Perdón de San Isidoro de León. Según hemos descrito en el inicio de este trabajo la fachada está compuesta por un paño central entre gruesos contrafuertes en el que se colocaron todos los elementos analizados: a saber y de abajo hacia arriba: vano de acceso con arquivoltas que descansan en columnas, tímpano decorado, figuras apostólicas en los laterales, remate superior en tejaroz, nivel de ventanas y finalmente remate en forma de frontón.

Llegados a este punto debemos trazar una línea visual vertical recta que unifique de manera global toda la fachada, para de algún modo poner en relación la figura de Cristo crucificado y resucitado con los elementos que el

ha logrado reflejar de manera muy clara el hecho de que el mundo del pecado y del infierno está "superedificado" por el mundo divinal.

${ }^{76}$ Entre los muchos casos a los que podríamos aludir, destaca por ejemplo el de la iglesia de Rheinau, que según A. REINLE, "Les débuts de la sculpture romane dans la région du lac de Constanze", Cahiers de Civilisation médiévale, XV, 3, Poitiers, 1972, pp. 179-191, especialmente pp. 182-183, debe interpretarse de abajo hacia arriba, es decir desde el hombre amenazado por los pecados terrenales, hasta la ascensión a la beatitud eterna que le lleva al Salvador, en la parte alta del tímpano.

${ }^{77}$ Entre algunos de los edificios que podemos citar con una distribución similar en fachada destacamos la iglesia de Saint-Jouin, con idéntica composición de puerta, vano y remate superior en forma de piñón: vid. I. LABANDEMAILFER, Poitou Roman, Yonne, 1957, pp. 179-181.

${ }^{78}$ La fachada de Notre-Dame-la-Grande de Poitiers, ha sido recientemente estudiada en la obra M-T. CAMUS Y C. AndRAult-Schmitt, Notre-Dame-la-Grande de Poitiers. L'oevre romane, Paris, 2002. 
artífice de la fachada colocó en los niveles superiores.

Parece claro que la alusión a la Gloria Celestial tras la resurrección de los muertos fue un recurso teológico frecuente dentro del arte medieval. No es necesario recordar la importancia que la luz y las visiones celestiales tenían dentro de los programas teofánicos en los que se expresaba la resurrección de Cristo muerto; y de igual manera tampoco parece inusual el simbolismo que en ocasiones se le va a atribuir al vano como fuente de luz real, pero también simbólica ${ }^{79}$.

La ventana, como fuente natural de luz, se prestaba entonces fácilmente a lecturas relacionadas con la manifestación material en la tierra de la divinidad cristiana. Así, son muy conocidos los textos de Plotino ${ }^{80}$, Dioniso Aeropagita, Honorio Augustodonensis ${ }^{81}$, o el pro-

-

${ }^{79}$ Parece innecesario insistir en que la luz fue, desde los primeros tiempos del cristianismo, considerada como un elemento de fuerte sentido sagrado. Sabemos que el cristianismo heredó de manera íntegra toda la simbología referente a la luz que durante el mundo antiguo pagano había estado contenida en la figura de Helios. La reinterpretación cristiana vendría a través de la figura de Cristo nimbado, de cuya aureola surgen fuertes rayos de luz. Parece claro que el primer ejemplo de esta índole en el que los estudiosos dudan de si se trata de una representación de Helios o de Cristo como "Rey", es el conocido mosaico del techo del mausoleo preconstantiniano, hoy en el subsuelo de San Pedro del Vaticano. Se suele considerar este mosaico como de finales del siglo II y por lo tanto de la Familia de los Julios: véase J. BECKWITH, Op. cit., p. 23. Con este ejemplo tan temprano de la iconografía paleocristiana, parece clara la unión entre el simbolismo de la luz y la figura de Cristo en Ascensión. No debemos olvidar, aunque incidamos en ello más adelante, que el comentado mosaico narra una escena de elevatio ad sidera, o en su vertiente cristiana de Ascensión. Sobre la iluminación y los matices lumínicos de las primitivas basílicas cristianas véase R. KRAUTHEIMER, Op. cit., p. 51 y E. CARAZO Y J. M. OTXOTORENA, Arquitecturas centralizadas: el espacio sacro de planta central: diez ejemplos en Castilla y León, Valladolid, 1994, en particular pp. 60-61.

${ }^{80} \mathrm{Sin}$ duda fue Plotino el autor que durante la Antigüedad tardía asentó las bases para el desarrollo que las teorías de la luz van a tener en los siglos medievales. En sus escritos hereda la tradición platónica del estudio de la belleza como categoría estética y tal como señala M. BARASCH, $O p$. Cit., Madrid, 1999, en p. 47: "Plotino toma los ejemplos artísticos de las observaciones de la luz, el color y el brillo, y sus ejemplos muestran claramente su fascinación por dichos fenómenos. El encanto del color y de la luz del sol son para él los principales ejemplos de una belleza simple, indivisible". Sobre la teoría de la belleza y la luz de Plotino, véase: Ibidem, pp. 42-47.

${ }^{81}$ Honorio Augustodunensis: De Gemma Animae, (Edición a cargo de J. Durán Pérez), Madrid, 1990, I, cap. CXXVI, alude de nuevo al simbolismo de la ventana con las siguientes palabras: "Las ventanas transparentes que alejan pio Abad Suger, sin duda el ejemplo más conocido en la exaltación de la luz como elemento simbólico ${ }^{82}$. Las palabras que recogemos en este fragmento, resumen ellas solas toda la teoría de la luz y las múltiples lecturas posibles que la luz y el vano tuvieron en la arquitectura medieval.

Quienquiera que seas, si deseas ensalzar la gloria de las puertas, que no te deslumbre el oro ni el gasto, sino la labor de la obra.

La obra noble brilla, pero que esta obra que brilla con nobleza ilumine las mentes para que siguiendo las verdaderas luces lleguen a la luz verdadera, donde Cristo es la Verdadera Puerta.

La puerta dorada define de esta manera esta luz interior: la mente aletargada se eleva hacia la verdad pasando por lo material y primero sumida en el abismo, resurge a la vista esta luz ${ }^{83}$.

La luz, era por lo tanto un elemento indispensable en el tránsito hacia la gloria tras la muerte. Algo, que tal y como señala S. Silva y Verástegui a propósito de la lámpara situada en la habitación donde muere San Millán en el marfil de la Cogolla, alude a la lumen gloriae, que acompañaba a los difuntos en su tránsito al cielo $^{84}$.

Según lo visto, esa debió ser la intención que los artífices de la fachada occidental de Saint Pierre de Angoulême tuvieron en mente a

el mal tiempo y permiten el paso de la luz, son los doctores que se enfrentan al turbión de las herejías y derraman a la luz de la doctrina de la iglesia. El vidrio en las ventanas a través del cual pasa el rayo de la luz, es la mente de los doctores que contempla misteriosamente las cosas divinas como por así decirlo a través de un espejo".

${ }^{82}$ El abad Suger de Saint-Denis fue el teólogo medieval que más va incidir en el simbolismo de la luz. Lo hará a través del llamado anagogicus mos (lit. "el método de la elevación"), según el cual a través de la luz y el refulgir de los materiales preciosos se podría ascender desde el mundo material al espiritual. Para un breve análisis de las teorías de Suger; vid. M. BARASCH, Op. cit., pp. 85-89. Véase también E. PANOFSKY, El Abad Suger. Sobre la Abadía de SaintDenis y sus tesoros artístiscos, Madrid, 2004.

${ }^{83}$ Estos son los versos que el propio abad Suger mandó grabar en las puertas de la basílica de Saint-Denis: E. PANOFSKY, Op. cit., p. 65.

${ }^{84}$ S. SILVA Y VERÁSTEGUI, "Los sepulcros de los santos constructores del camino a Santiago de Compostela", Los caminos de Santiago. Arte, historia, literatura (María del Carmen Lacarra Ducay, coord.), Zaragoza, 2005, pp. 129-167, en particular p. 148 . 
la hora de colocar un gran ventanal de medio punto sobre la puerta de acceso al templo; o lo que es lo mismo, con una función idéntica a la del rosetón de la fachada occidental del Pórtico de la Gloria ${ }^{85}$.

La luz que por ellas entra, evoca la lumen gloriae que desde el mundo paleocristiano acompaña a los muertos en su tránsito hacia la vida eterna. No en vano, en la fachada francesa y a pesar de la restauración, fue esculpido en la parte alta del conjunto, sobre la ventana y en línea vertical con la puerta, la figura de Cristo Majestad ascendiendo a los cielos ${ }^{86}$.

Si atendemos a las descripciones hechas hasta la fecha de la portada del Perdón, ninguna de ellas se ha detenido en la observación de un elemento, que debido a su mal estado de conservación, es realmente difícil de identificar. Algo, que lo ha llevado a pasar desapercibido a la hora de establecer una lectura del conjunto. Se trata de unos sillares pétreos maltrechos en forma rectangular, que engastados en el despiece del muro, presentan un tamaño grueso en la parte inferior, para hacerse más finos y llegar casi a desparecer en la superior (fig. 11).

El comentado resto pétreo, formado por una sola pieza, se coloca en eje vertical con la ventana de la fachada, así como con el portal de acceso inferior, algo que no debe llamar la atención, si lo comparamos con otros ejemplos de diferentes fachadas románicas, donde como hemos visto, no era inusual la colocación de una figura esculpida en los remates de las fachadas.

Para poder llevar a cabo la identificación de este elemento, debemos recurrir a la conocida obra de J. M ${ }^{\mathrm{a}}$. Quadrado, Recuerdos y bellezas de España ${ }^{87}$. Nos interesa, para nuestro propósito, detenernos en una de las ilustraciones que acompañan al texto, obra del pintor decimonónico, Francisco Javier Parcerisa. El dibujo

-

85 S. MORALEJO, "La imagen...”, pp. 243-244.

${ }^{86}$ Idéntico esquema compositivo sigue la fachada de Notre-Dame-la-Grande de Poitiers, donde fue tallada la figura de un Cristo sobre el piñón de la fachada, encima de la puerta de acceso y la ventana. La figura de Cristo posee nimbo crucífero y manto a la antigua, un libro cerrado en la mano izquierda, mientras que con la derecha bendice. Los pies desnudos se colocan sobre un escabel. Sobre esta figura vid. M-T., CAMUS, "Des Images à lire, méditer, admirer", M-T. CAMUS y C. ANDRAUlT-SChMitT, Op. cit., pp. 249307, especialmente pp. 278-279.

87 J. M. QUADRADO, Recuerdos y Bellezas de España. Asturias y León, 1855, (facsímil, Gijón, 1977). en cuestión, reproducido en la lámina 347 (fig. 12), nos muestra de manera clara la cabecera gótica del edificio, el ábside sur del templo románico $^{88}$, la zona alta de la nave central y el arranque del crucero ${ }^{89}$, la portada del Cordero ${ }^{90}$, la biblioteca renacentista de la Colegiata y por último la Puerta del Perdón ${ }^{91}$.

$\square$

${ }^{88}$ Observamos que en la fecha de ejecución del dibujo, anterior a la publicación de la obra en el año 1855, la única ventana que se ha representado, estaba tapiada, por lo que deducimos que fue en una fecha posterior y posiblemente con las labores de restauración del edificio cuando se retiró el muro de cierre que la cegaba. Deducimos además por el dibujo que en este momento el ábside sur no estaba totalmente exento en su base, pues se adosaban a él dos zócalos, uno que según el diseño recorrería perimetralmente la cabecera gótica y otro zócalo continuo que arrancaba en el contrafuerte derecho de la portada del Perdón y en el que estaba embebido el fuste y la basa de la columna del ábside. Actualmente nada queda de estos zócalos.

${ }^{89}$ En el dibujo observamos el precario estado de la cubierta del brazo sur del transepto, con grandes desajustes y cambios de nivel en el ensamble con la nave central y que según parece, en este momento acusaban derrumbe.

${ }^{90}$ Resulta muy llamativo el gran detallismo con el que Parcerisa ha representado hasta los mínimos detalles de esta zona del edificio. Así, si observamos detenidamente la portada del Cordero, advertimos la existencia de una figura en la albanega izquierda, posiblemente la de San Isidoro. El sombreado de la zona nos permite afirmar que ya por entonces se encontraban empotradas en esta fachada meridional las lajas con las representaciones zodiacales y el conjunto de los músicos del Rey David. Idéntico detallismo utiliza el artista para representar el remate barroco de la fachada con la alternancia de triglifos y metopas de raigambre clásica y el conocido remate con la escultura ecuestre de San Isidoro Matamoros venciendo a los musulmanes en la batalla de Baeza. Sobre la comentada iconografía vid. E. FERNÁNDEZ GONZÁLEZ, "La iconografía isidoriana en la Real Colegiata de León", Pensamiento medieval Hispano, (J. M. Soto Rábano, coord.), Madrid, 1998, pp. 141-148. Sobre los añadidos barrocos, en concreto la peineta de la fachada del Cordero de San Isidoro véase: E. MORAIS VALlEJO, Aportación al barroco en la provincia de León. Arquitectura religiosa, León, 2000, en concreto pp. 266-268.

Sobre esta portada Quadrado nos dice: "la portada lateral y al presente única metida entre este y otro cuerpo saliente que corresponde a la biblioteca y que por su género y posición viene a formar colateral con la capilla mayor": J. Mª. QUADRADO, Op. cit., p. 339.

${ }^{91}$ En torno a la fecha de creación del dibujo de Parcerisa, la portada presentaba bastantes desperfectos en los contrafuertes laterales. Observamos el derrumbe de algunos sillares en la parte superior decreciente de los mismos, así como el total deterioro de las esculturas zoomórficas que los remataban. Las dos del lado derecho se encontraban en estado ruinoso, mientras que la del lado izquierdo había desaparecido debido sin duda al paso del tiempo y la intemperie meteorológica. La misma que llevó a la desaparición del relieve central de la parte alta de la fachada.

En la actualidad, los cuatro animales híbridos que encontramos rematando los contrafuertes de la fachada, son sin lugar a duda piezas de restauración, hecho que hemos 
Es en esa misma Puerta del Perdón, donde observamos, en la parte alta de la fachada, la presencia del comentado elemento anteriormente inidentificable. Tal y como dibuja Parcerisa, se trataba de una escultura de formato rectangular que representa una figura humana, vestida con toga larga que cae en pliegues sobre el hombre izquierdo. Sus pies se apoyan en una estructura similar a una ménsula o mocheta que parece engastada en el muro. Son perfectamente visibles los brazos, tal vez en actitud de orante o de bendición, y la cabeza.

Según esto, es posible que el elemento tallado en la parte alta de la Portada del Perdón fuese una escultura con una representación antropomórfica. Lo que no está del todo claro es de qué figura se trata.

Para confirmar la identificación de este relieve con una figura humana que hemos hecho a través del dibujo de Parcerisa, debemos acudir a la llamada Crónica General de España y en concreto a la Crónica de la Provincia de León, escrita por D. José García de la Foz, en torno al año $1867^{92}$.

Si bien en su Crónica, el autor hace una breve descripción del edificio, no llega en ningún caso a describir, ninguna de las tres fachadas esculpidas con las que contó originariamente la Colegiata ${ }^{93}$. Sin embargo, la Crónica se acompaña por una serie de grabados o litografias en blanco y negro, de los diferentes monumentos de la ciudad de León, en una calidad y

podido comprobar al fotografiar las bases de dichas esculturas y en las que es perfectamente legible la letra -R-, correspondiente a las labores de restauro del templo, que también encontramos en multitud de figuras, capiteles y sillares del edificio. El resto de la fachada ha llegado a nosotros, aparentemente en el mismo estado que captó en su momento Parcerisa. En lo que respecta a la información dada por $\mathrm{J}$. $\mathrm{M}^{\mathrm{a}}$. Quadrado, este nos dice: "Estos ángulos y recodos felizmente combinados con la diversidad de alturas y de estilos, la capilla mayor que descuella, el brazo del crucero que avanza con su tapiada puerta (...)"; Ibidem, p. 339. Hecho que también ha sido captado fielmente por Parcerisa al representar la puerta en cuestión tabicada.

92 J. GARCÍA DE LA FOZ, Crónica General de España ó sea Historia Ilustrada y Descriptiva de sus provincias, Madrid, 1867.

${ }^{93}$ Ibidem, p. 67, donde se refiere a la zona del transepto en los siguientes términos: "El brazo principal de la iglesia, hasta el crucero, cuenta seis arcadas, ocupadas las tres primeras por el coro levantado en alto. El crucero es algo más bajo que la nave mayor, y lleva festoneados sus arcos de lóbulos ó colgadizos. Tanto él, como las naves reciben la luz por ventanas bizantinas engalanadas por dentro y fuera, y dominando en las cornisas el dibujo ajedrezado". detallismo muy inferior a la que encontrábamos en los dibujos de Parcerisa. Es en la página 81 donde se representó una vista lateral de la Colegiata y desde la cual es perfectamente visible la fachada del Perdón, la Portada del Cordero y otra serie de partes del edificio, tales como la biblioteca renacentista, el ábside sur del templo, la cabecera gótica y el brazo sur del crucero, todos ellos ya presentes en el dibujo de Parcerisa.

También en la parte alta de la fachada volvemos a encontrar la representación de una figura humana, con los pies sobre un supedanium y las manos sobre el pecho en actitud de bendecir.

Con los datos expuestos hasta el momento, creemos posible aportar una serie de ideas para complementar la lectura iconográfica del conjunto escultórico de la fachada del Perdón. Así, además de aparecer representados los tres momentos cruciales de la vida de Cristo: Crucifixión, Santo Entierro y Ascensión a los cielos, todos ellos temas iconográficos de la más pura tradición cristiana ${ }^{94}$, debemos señalar como rasgo distintivo, la exaltación que se hace en la fachada de la idea de Resurrección y Ascensión a los cielos; hasta el punto convertirse en "idea rectora" del programa de la portada. En ella, se pone el acento en la fe de la nueva vida representada por las palabras del Redentor y atestiguada por la presencia de los apóstoles Pedro y Pablo ${ }^{95}$. Aquí la Resurrección y Elevación a los cielos adquiere un carácter físico sintetizado no sólo en la ascensión helenística del tímpano, tal y como hemos señalado, sino a través de la elevatio física de la figura de Cristo, muy posiblemente representada, en el momento del tránsito, en la parte alta de la fachada.

En este sentido, la portada leonesa refleja el ideal cristiano heredado de la iconografía tardoantigua romano-cristiana según la cual la figura de Cristo se eleva a los cielos tras la muerte como Rey del Cosmos, que a través de

-

94 Para W. WeISBACH, Op. cit., p. 97, el "prototipo ideal de programa iconográfico cluniacense vendría marcado por la representación del Cristo apocalíptico, como Rey del Cielo, o como Salvador, así como de otra serie de temas tales como profetas, apóstoles y hechos narrados en el Antiguo y Nuevo Testamento".

95 No vamos a insistir más en las numerosas representaciones de Pedro y Pablo como testigos del tránsito de los difuntos dentro de la escultura de los sarcófagos paleocristianos. 
la luz radiante, en este caso materializada por la ventana, pone fin a las tinieblas de la muerte, representada en la parte inferior de la fachada ${ }^{96}$. Con la doble representación del momento de la elevación a los cielos de Cristo, la iconografía de la fachada adquiere connotaciones que van más allá de lo meramente teofánico, donde Cristo se nos muestra como Maiestas celestial que señala el acceso a la basílica mediante la "Puerta del Cielo", ideas todas ellas presentes dentro del arte promovido bajo la influencia de la Reforma Gregoriana ${ }^{97}$.
Sin embargo, el precario estado de la escultura, la complejidad iconográfica de la fachada y las evidentes reformas de esta zona del edificio, imposibilitan llevar a cabo, por el moemnto, una identificación segura de la pieza. Nos limitamos tan sólo a proponer una vía de investigación sobre la que continuaremos indagando,a la espera de poder ofrecer más datos que clarifiquen y aseguren una correcta lectura de dicha obra, sin duda una de las más interesantes del arte románico hispáno.

${ }^{96}$ Debemos recordar aquí la anteriormente citada iconografía de Cristo ascendiendo a los cielos del mosaico del subsuelo vaticano, donde se puso especial interés en representar la luz surgida del nimbo de Cristo.

${ }^{97}$ Este simbolismo también ha sido puesto de relieve para la interpretación iconográfica de la portada de NotreDame-la-Grande de Poitiers, por M-T Camus, quién considera que el Cristo en mandorla bendiciendo debe ser visto como una imagen de esperanza para los cristianos y puente de unión entre la vida terrena y la vida eterna de Dios, después de la muerte; vid. M-T. CAMUS, Op. cit., p. 279. 


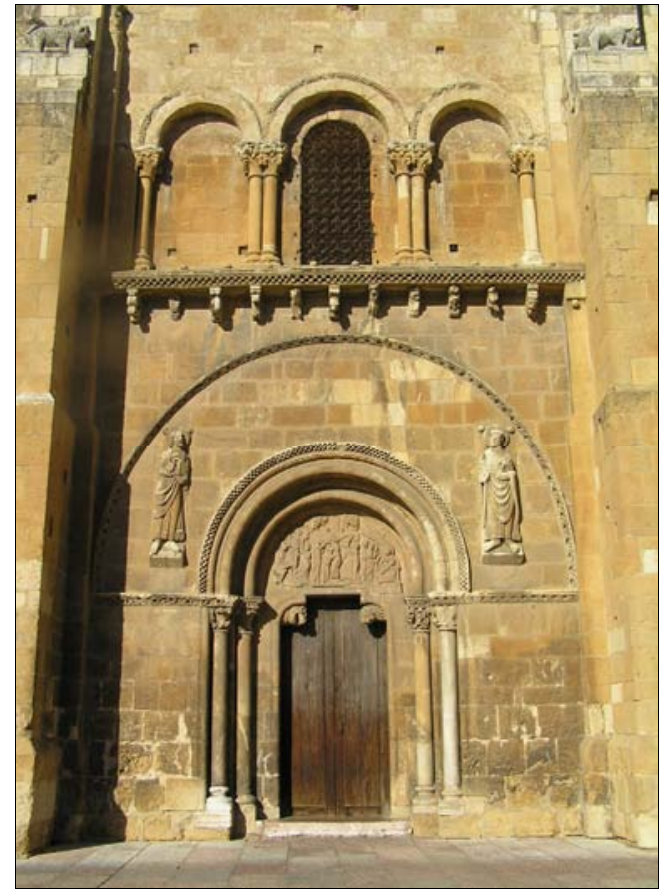

- Fig. 1. León, Real Colegiata de San Isidoro, Puerta del Perdón. (Foto autor).

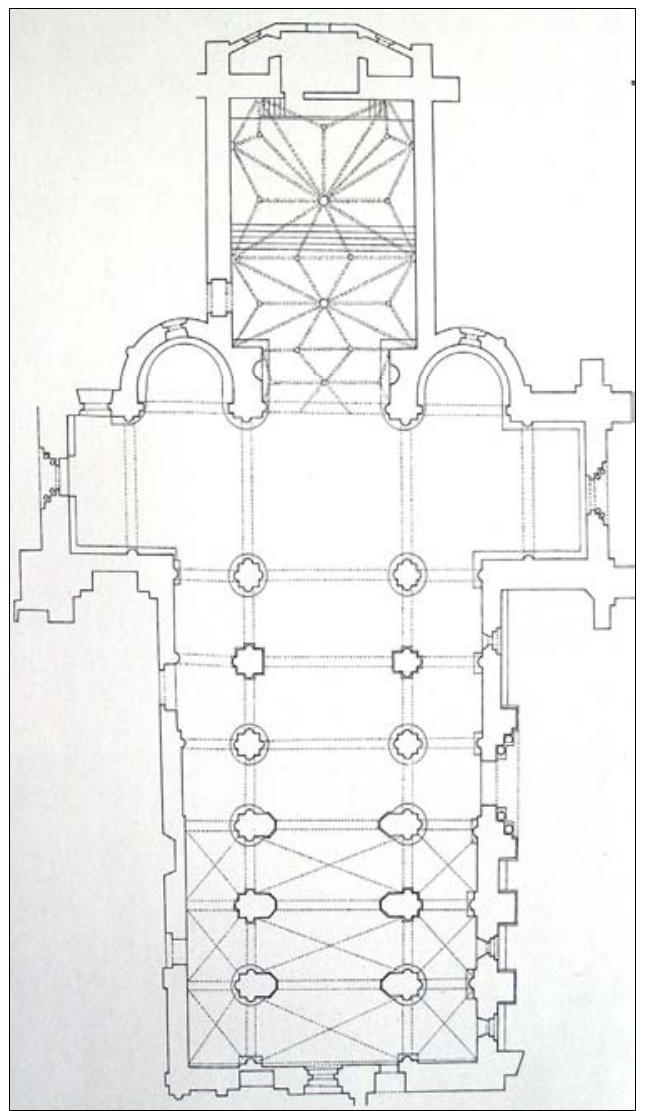

- Fig. 3. León, iglesia de San Isidoro, Planta. (Según A. Viñayo).

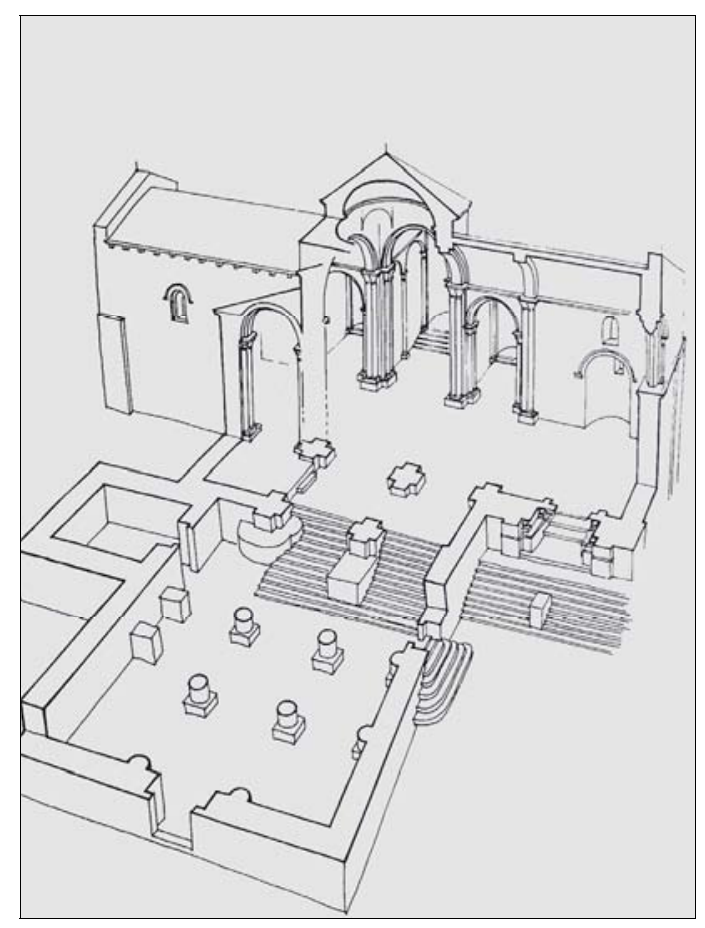

- Fig. 2. Silos, iglesia de Santo Domingo, Planta y alzado. (Según I. Bango Torviso).

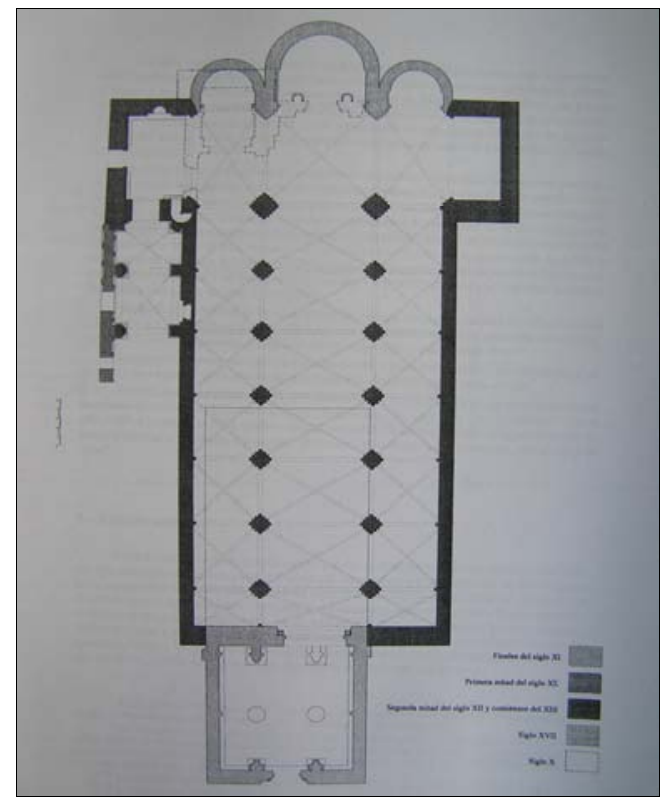

- Fig. 4. Sahagún, monasterio de San Benito, Planta. (Según M. P. Sánchez Pérez). 


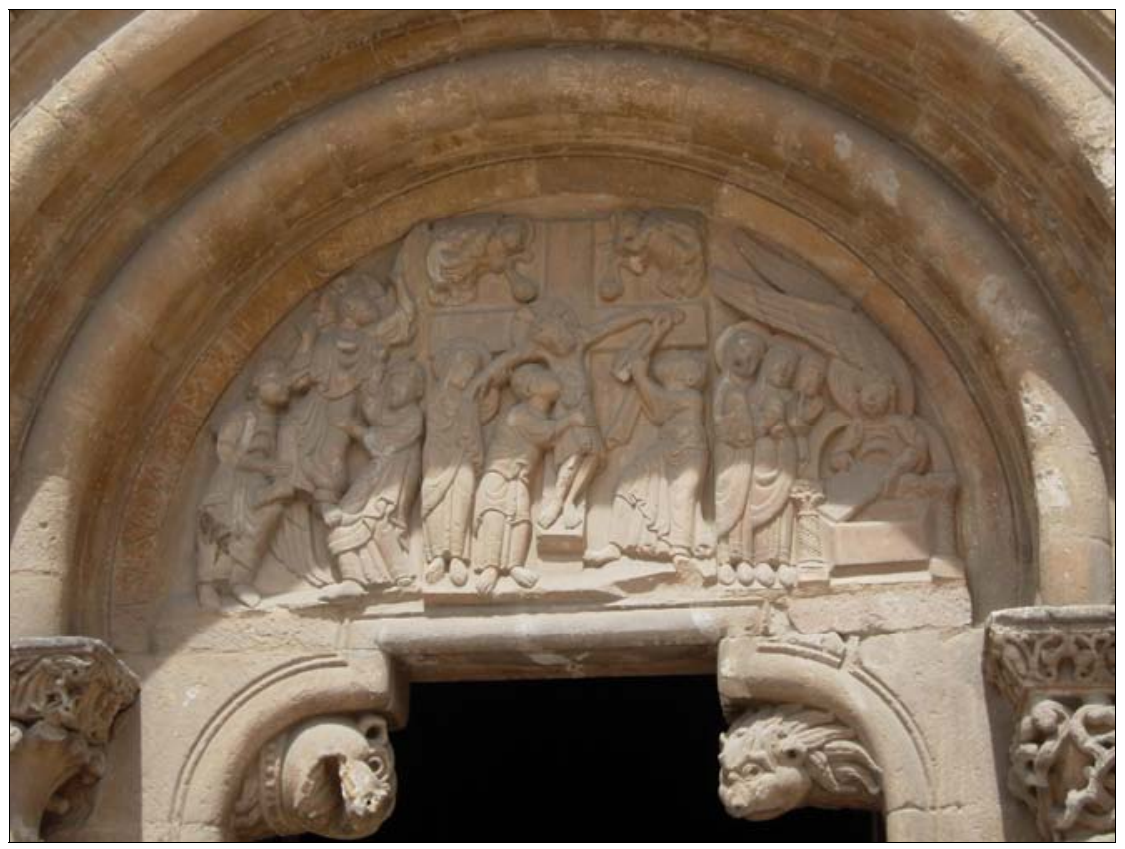

- Fig. 5. León, Real Colegiata de San Isidoro. Tímpano de la Puerta del Perdón. (Foto autor).
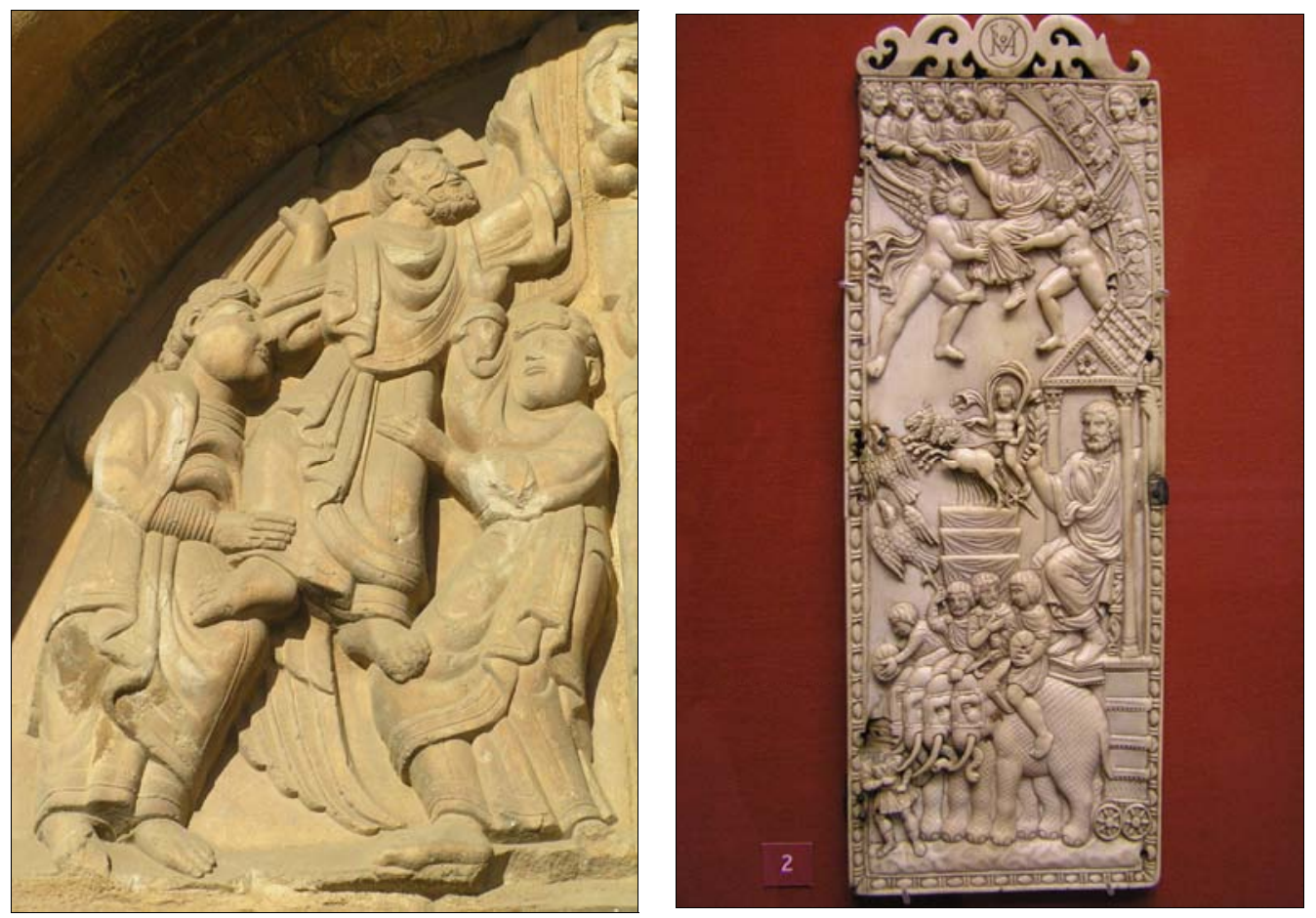

- Fig. 6. León, Real Colegiata de San Isidoro, Ascensión. Londres, British Museum, Díptico Symmachi. (Fotos autor). 


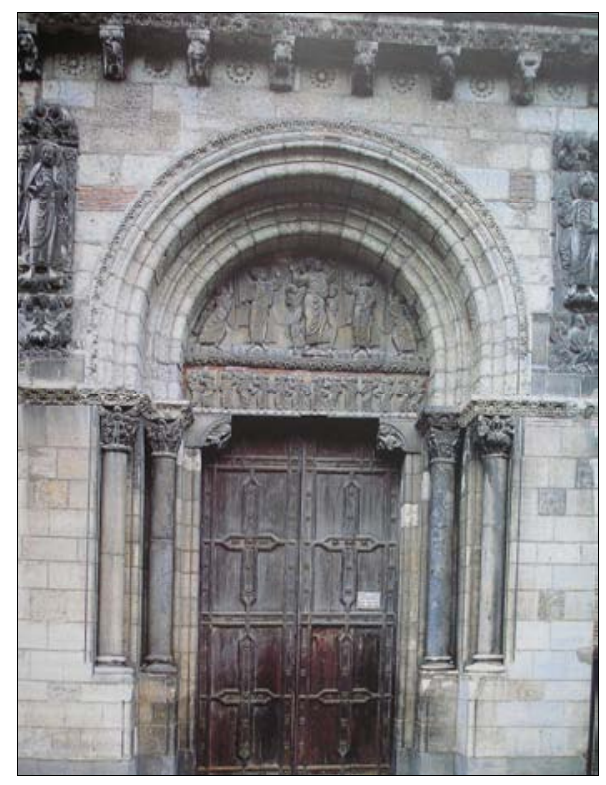

- Fig. 7. Toulouse, iglesia de Saint-Sernin. Puerta Miégeville. (Foto autor).
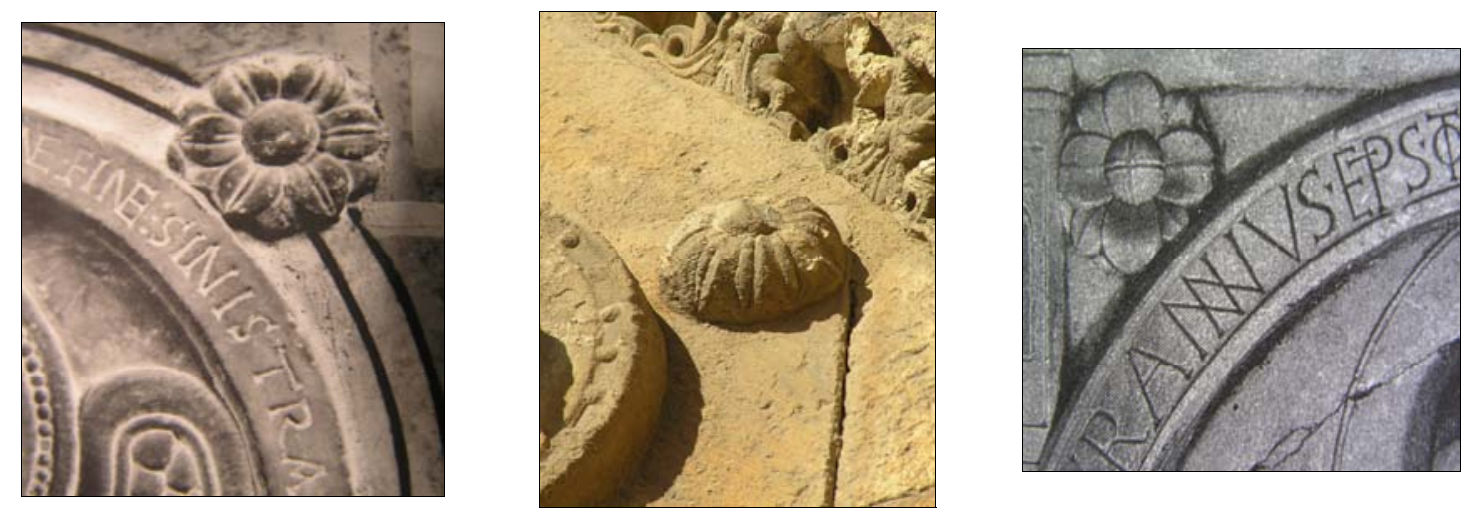

- Fig. 8. Toulouse, iglesia de Saint Sernin, relieve del deambulatorio. León, iglesia de San Isidoro, relieve de Puerta del Perdón. Moissac, claustro, relieve de uno de los machones. (Fotos autor).

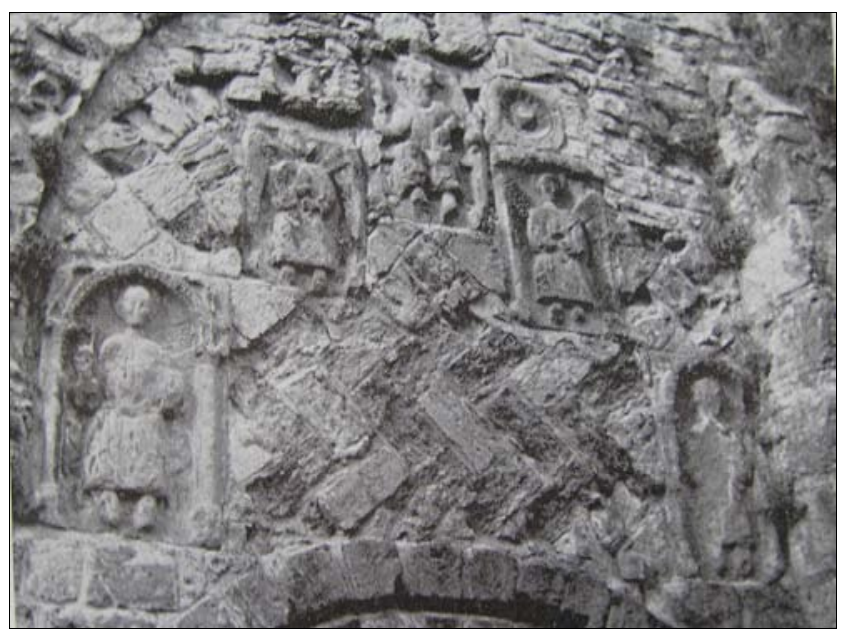

- Fig. 9. Marcilhac, iglesia, Portada. (Según M. Durliat). 

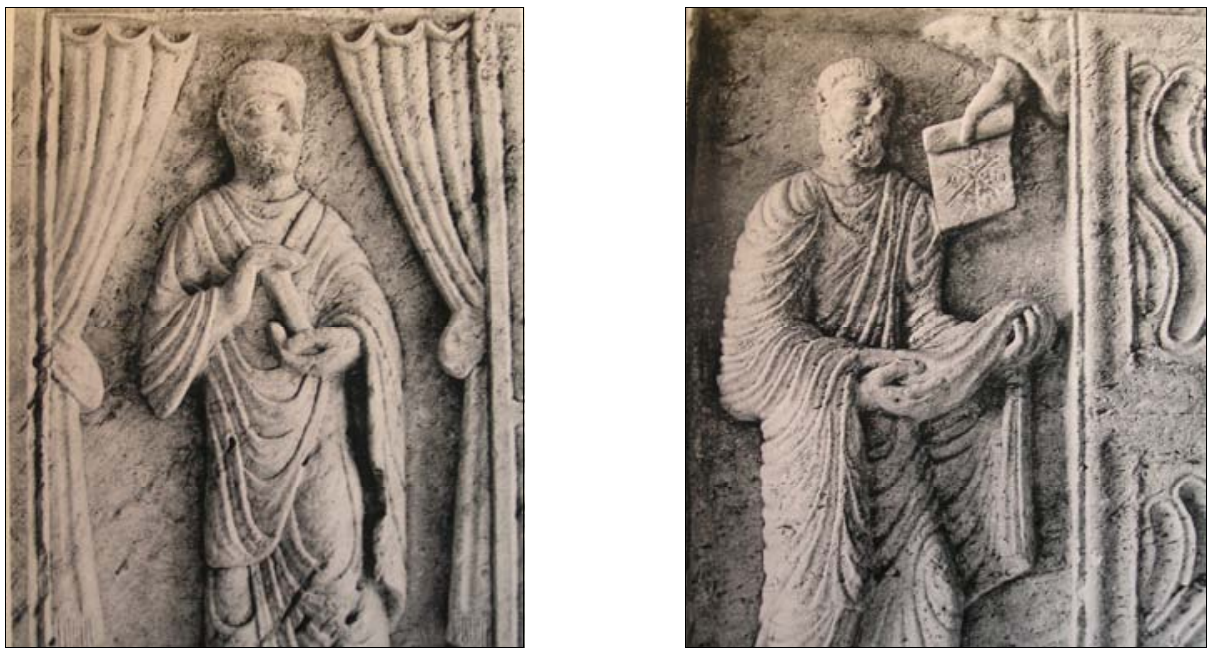

- Fig. 10. Tarragona, Museo de la Necrópolis, Sarcófago, Pedro y Pablo. (Según P. De Palol).

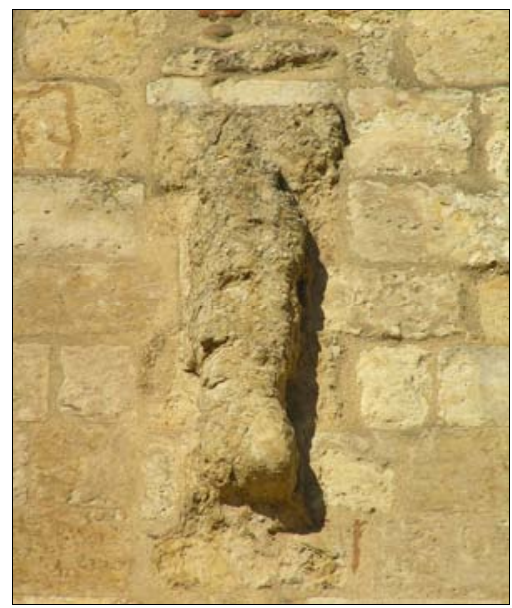

- Fig. 11. León, Real Colegiata de San Isidoro, Puerta del Perdón, restos de la figura del remate superior.
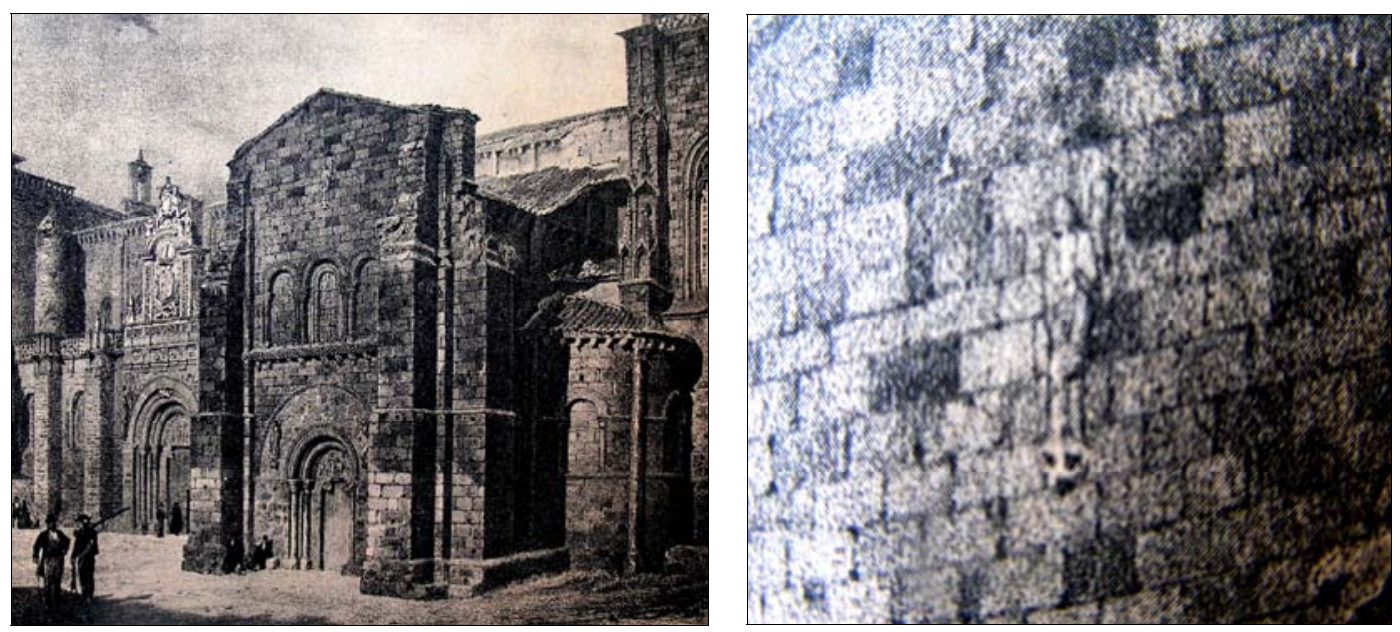

- Fig. 12. J. M. Quadrado, Recuerdos y bellezas de España, dibujo de Parcerisa, vista de la Real Colegiata de San Isidoro de León. 